GLOBAL WATER PATHOGEN PROJECT

PART THREE. SPECIFIC EXCRETED PATHOGENS: ENVIRONMENTAL AND EPIDEMIOLOGY ASPECTS

\title{
ASCARIS SPP.
}

\section{Samuel Ore Asaolu}

Obafemi Awolowo University, Ife-Ife

Ile-Ife, Nigeria

Ifeanyi Emmanuel Ofoezie

Obafemi Awolowo University, Ife-Ife

Ile-Ife, Nigeria 


\section{Copyright:}

\section{cc) (i) (2) \\ BY SA}

This publication is available in Open Access under the Attribution-ShareAlike 3.0 IGO (CC-BY-SA 3.0 IGO) license (http://creativecommons.org/licenses/by-sa/3.0/igo). By using the content of this publication, the users accept to be bound by the terms of use of the UNESCO Open Access Repository (http://www.unesco.org/openaccess/terms-use-ccbysa-en).

\section{Disclaimer:}

The designations employed and the presentation of material throughout this publication do not imply the expression of any opinion whatsoever on the part of UNESCO concerning the legal status of any country, territory, city or area or of its authorities, or concerning the delimitation of its frontiers or boundaries. The ideas and opinions expressed in this publication are those of the authors; they are not necessarily those of UNESCO and do not commit the Organization.

\section{Citation:}

Asaolu, S.O. and Ofoezie, I.E. (2018). Ascaris spp. In: J.B. Rose and B. Jiménez-Cisneros (eds), Water and Sanitation for the 21st Century: Health and Microbiological Aspects of Excreta and Wastewater Management (Global Water Pathogen Project). (L. Robertson (eds), Part 3: Specific Excreted Pathogens: Environmental and Epidemiology Aspects - Section 4: Helminths), Michigan State University, E. Lansing, MI, UNESCO. https://doi.org/10.14321/waterpathogens.41

Acknowledgements: K.R.L. Young, Project Design editor; Website Design Agroknow (http://www.agroknow.com)

Last published: April 12, 2018 


\section{Summary}

Ascariasis is a disease caused by infection with the intestinal roundworm, Ascaris lumbricoides. A. lumbricoides is regarded as a different species from the pig ascarid, $A$. suum, which has also been reported infective to humans. A. lumbricoides occurs worldwide, but it is more prevalent in tropical and subtropical countries, in humid and warm climates, and areas where poverty, poor hygiene, and inadequate sanitation prevail. Over eight hundred million people are infected globally, with the greatest burden in young children.

Adult worms are creamy white to yellowish, often translucent with a pinkish tint. Females are 200 to $490 \mathrm{~mm}$ long and 3-6 mm wide. Males are 150-310 mm long and 2-4 $\mathrm{mm}$ wide. Eggs appear golden brown, round to ovoid, measuring $45-75$ by $35-40 \mu \mathrm{m}$.

People become infected with Ascaris by ingesting the infective eggs, possibly as contaminants of food or drink. In the intestine, the eggs hatch into larvae, which migrate through the liver to the lungs, up the trachea and are then swallowed, thereby returning to the intestine where they mature as adult male and female worms. Following copulation, females start releasing eggs about seventy days after ingestion of eggs. Diagnosis is by detection of eggs in host faeces. Ascaris eggs must embryonate in the environment for around 3-6 weeks, depending on temperature, before they become infective, and can persist in the environment for over six years.

Most infections are asymptomatic but some may show signs typical of asthma or pneumonia in the early stages. Abdominal pain, nausea, vomiting, malnutrition, passing of worms with vomit or in stool, bowel obstruction and pancreatitis may occur in later stages.

In endemic areas, the immediate environment is contaminated due to open defecation, and people may have life-long exposure to infection. Control involves environmental sanitation, chemotherapy, health education, and prevention of indiscriminate defecation, improper disposal of human excreta and use of untreated night soil for manure in agriculture.

As efficacious drugs are available, regular mass drug administration, targeted at school-age children, is currently being adopted by the WHO for the integrated control of ascariasis globally.

However, the impact of this intervention will depend on the provision of safe water supply and the facility for safe disposal of human excreta. Without this infrastructure, the environment will remain a source of infection due to contamination.

\subsection{Epidemiology}

Human and animal ascariasis together constitutes one of the most important global public health challenges. The disease is widespread and is found worldwide but particularly more common in Sub-Saharan Africa and Southeast Asia (Bethony et al., 2006; Pullan et al., 2014). Transmission is through the faecal-oral route; eggs are ingested following contact with fecally or sludge contaminated food and/or soil, or the deliberate act of eating contaminated soil (Bethony et al., 2006). Thus, ascariasis is a perfect example of an environmental disease.

\subsection{Global Burden of Disease}

\subsubsection{Global distribution}

Ascaris lumbricoides is cosmopolitan in distribution. However, A. lumbricoides, like the other soil-transmitted helminths (STHs), Trichuris trichiura and the hookworms, Ancylostoma duodenale and Necator americanus thrive in places where the soil is warm and humid, sanitation is poor and poverty and ignorance prevail (Asaolu et al., 2002a). It is estimated that in 2010 about 818 million (771.7-891.6 million) people were infected with Ascaris lumbricoides (Pullan et al., 2014). Ascariasis is prevalent in at least 150 of the 218 countries of the world. The overall global prevalence was roughly estimated at 22\% (Crompton 1989). The distribution of the global burden of ascariasis shows that South America, Central America and the Caribbean host $8.3 \%$, Africa and the Middle East, $16.7 \%$ as well as Central and Southeast Asia and the Oceania region $75 \%$ of cases (Shoff, 2015).

In many endemic communities, prevalence may be in excess of $80 \%$. Prevalence varies widely among the endemic countries and the worm presents a patchy and uneven distribution among the communities in the endemic countries, and among different households in the same community (Robertson et al., 1989). In Nigeria, for example, surveys from various authors showed that prevalence varied from 0.9 to $98.2 \%$ in places (Crompton, 1989; Holland and Asaolu, 1990). People are exposed to infection from birth and are continually at risk from reinfection because of poor sanitation, low standard of personal hygiene and constant exposure to enormous numbers of $A$. lumbricoides eggs discharged by the female worms to the environment through the faeces of infected subjects daily.

All ages are susceptible to ascariasis although prevalence and intensity are usually higher among schoolage children than other age groups. Classical age related distribution patterns indicate that prevalence peaks between ages 4 and 14 years. Intensity of infection measured by the number of worms expelled by the host after chemotherapy or the number of eggs counted per gram of host faeces shows that children harbour more worms than adults. The higher rates observed among the children appear to be related to higher exposure levels among children than immunity to infection among older age groups. Distribution of $A$. lumbricoides as in other parasitic worms, in a population, is known to be over-dispersed, such that majority of individuals in the population carry few or no worms while a smaller percentage of people are heavily infected (Anderson and May, 1991).

Since 2001, the target was set by the World Health 
Organization (WHO) for endemic countries to ensure that at least $75 \%$ of school-aged children at risk of soiltransmitted helminthiases would have access to treatment with anthelmintic drugs by 2010. The adoption of preventive chemotherapy by the mass distribution of anthelmintic to school-age children by the WHO for the global control of the soil transmitted helminths (STHs) (WHO, 2006a) has since led to considerable reductions in the prevalence and intensity of $A$. lumbricoides and the other soil-transmitted helminths in many of the endemic countries (Uniting to Combat NTDs, 2015).

\subsubsection{Symptomatology}

A. lumbricoides infections show no symptoms in more than $85 \%$ of infected people, especially when the number of worms present is small (Dold and Holland, 2011). Moderate to heavy infections cause various symptoms, depending on which part of the body is affected. Several larvae migrating from the intestine to the other organs are destroyed in the liver and lungs. The remains of the disintegrating larvae induce eosinophilic reactions. In the lungs, the migrating larvae cause slight cough, fever and skin rashes for a few days or, in areas where transmission is seasonal, there are severe symptoms of pneumonitis similar to asthma, persistent cough, shortness of breath, substernal pain and wheezing (Coles, 1985). Adult worms residing in the intestines may induce vague abdominal pain, nausea, vomiting, diarrhoea or bloody stools, nutrient malabsorption and increased nutrient losses in mild infections. In heavy infections, and especially in children, there may be restlessness, loss of appetite, severe abdominal pain, intermittent loose stools, constipation, fatigue, vomiting, weight loss, malnutrition, passing of worms from the anus or the mouth, abdominal distension and abnormal abdominal sounds.

\subsubsection{Morbidity}

The pathological problems associated with $A$. lumbricoides infection can be examined in four specific stages (a) larval migration, (b) adults worms in the small intestine, (c) complications and (d) allergic reactions (Pawlowski and Arfaa, 1985).

The adult worms in the intestine cause disordered changes in the mucosa and the muscle layers. There is villus atrophy, coarsening of mucosal folds, shortening of crypt depths, reduced mucus production and hypertrophy of the muscle layers of the intestinal wall (Tripathy et al., 1972). Chronic heavy infection of school-aged children in developing countries significantly contribute to protein energy malnutrition, reduced food intake, retarded growth, cognitive deficits and mental retardation (Stephenson et al., 1983).

The migrating larvae provoke inflammatory reactions in the intestinal mucosa, liver and lungs. Some of them become trapped and immobilised by eosinophils, leading to granuloma formation. In the lungs, the larvae moving from the blood capillaries into the air spaces puncture the capillaries resulting in haemorrhage and oedema of the alveoli. Alveolar sacs become filled with serous exudate.
There is infiltration of the peri-bronchial tissues with eosinophils and neutrophils with increased mucous production in the bronchi. This gives rise to cough, high fever, and bronchial asthma (Asaolu et al., 2002b). This condition, regarded as Loeffler effect, results in transient lung infiltration with blood eosinophilia, and is frequently caused by Ascaris larvae migrating through the lungs. The reaction is severe when the number of larvae is large or when transmission is seasonal as recorded by Gelpi and Mustafa (1967) in Saudi Arabia.

Severe complications in Ascaris infection are frequently associated with the large size and aggregating and migratory habits of the worm. Migration of worms from their normal location in the intestine can be induced by fever, ingestion of some drugs or food, and administration of surgical anaesthesia in the host. Worms which move to the stomach may become vomited (Villamizar et al., 1996). Obstruction of the upper respiratory tract has also been reported (Andrade-junior et al., 1992; Astral and Rogers, 1995; Pawlowski and Arfaa, 1985; da Silva et al, 1997; Villamizar et al., 1996; Xianmin et al., 1999). In heavy infections several worms may ball up to form a bolus and cause intestinal obstruction which may be accompanied by complications such as intussusceptions, volvulus, haemorrhagic infarction and perforation of the wall of the intestine (Tripathy et al., 1971; Blumenthal and Schultz, 1975; Crompton, 1989). Worms can invade the bile ducts, the liver, pancreatic duct, the appendix, surgical wounds and the peritoneum (Wani et al., 2010) where they cause abscesses.

A fatal case of multiple liver abscesses by $A$. lumbricoides in a 21-month-old child was reported in Sao Paulo by Rossi and Bisson (1983). In a fatal infection of a 2year-old South African girl, 796 Ascaris were recovered at autopsy from the ileum which had suffered torsion and gangrene (Baird et al., 1986). Nonfatal heavy infection cases of up to 990 worms have been recorded while there have been infections of intestinal obstruction with only 4 worms. The average worm burden in fatal cases was 659 (23-1978). Even infection with a single adult worm can be fatal if it migrates into the common bile duct, the pancreatic duct or the appendix. The frequency of such complications may be very low but they represent the main causes of acute abdominal emergencies in children in many endemic countries. The disability adjusted life years lost for ascariasis is estimated as 10.5 million years.

According to Coles (1985), the main cause for allergy and immunopathology to Ascaris appears to be raised antiAscaris IgE reacting with allergen and causing release of histamine. Laboratory workers who are not infected with Ascaris but who have inhaled antigens from the eggs, larvae or adults of the worm, have experienced allergic reactions such as asthma, eosinophilia, gastrointestinal disorder and urticarial (Arfaa, 1984; Tripathy et al, 1971). Presumably these workers are sensitized by inhaling and thereby swallowing airborne antigens escaping from the worm materials they handled in the laboratory. Hence it has been suggested that Ascaris is the most potent and therefore dangerous source of allergens routinely handled in the laboratory. It has been suggested that the abdominal 
symptoms of ascariasis are allergic in nature and must arise from the production of a toxin, or a peptide causing release of histamine, or allergens that result in immunopathology or a combination of these factors (Coles, 1975, 1985).

Annual global mortality due to ascariasis was initially estimated to range from 10,000 to 200,000 but more realistically, it was believed to be about 10,000 deaths per year (da Silva et al., 1997). The death rate may have been reduced considerably by the ongoing global integrated control programme of soil-transmitted helminths (of which A. lumbricoides is among) by the WHO (Uniting to Combat NTDs, 2014). In 2013, the global death rate ascribed to ascariasis was estimated at 4,500 (Hotez and Herricks, 2015), but the data are not available.

\subsection{Taxonomic Classification of the Agent}

\subsubsection{Taxonomy and physical description of the agent}

Ascaris lumbricoides is a parasitic worm which causes ascariasis disease in humans. It is the most common and prevalent nematode parasite infecting humans (Croll et al,
1982). Up to seventeen species of Ascaris have been recognized inhabiting the gastrointestinal tracts of mammalian hosts (Crompton, 1989; Shoff, 2015). A. lumbricoides has high host specificity for humans but it can also infect and reach sexual maturity in pigs. The worm has been reported to develop to some extent in other animals like bears and primates but in these hosts, the parasite has not been demonstrated to become sexually mature and produce eggs. Ascaris suum, a closely related species, has high host specificity for pigs but patent infections have also been reported in humans (Galvin, 1968; Eddy, 1985). A. suum has also occasionally been reported in cattle and sheep but has not attained sexual maturity in them. Questions have been raised as to whether A. lumbricoides and A. suum are the same or separate species in view of the fact that the two nematodes are indistinguishable morphologically, and they and their human and pig hosts often co-exist. However, detailed studies on the morphology, protein profiles, sex chromosomes and molecular genetics of the two worms have revealed important differences which imply that the two nematodes are separate species (see Crompton, 1989).

Ascaris lumbricoides is the type species of the genus and its systematic position is presented in Table 1.

Table 1: Classification of Ascaris lumbricoides (according to Guy, 2017)

\begin{tabular}{ll}
\hline Kingdom & Animalia \\
Phylum & Nematoda \\
Class & Secernentea \\
Order & Ascaridida \\
Family & Ascarididae \\
Genus & Ascaris \\
Species & A. lumbricoides \\
\hline
\end{tabular}

\subsubsection{Morphology}

Ascaris lumbricoides is the largest nematode inhabiting the human alimentary tract, usually found residing in the jejunum of the small intestine (Arfaa, 1984; Crompton and Pawlowski, 1985; Andrade-junior et al., 1992). Adult life worms are turgid and the colour is creamy white with pinkish tint. Male worms measure 15 to $31 \mathrm{~cm}$ in length, 2 to $4 \mathrm{~mm}$ in width and have posterior end curved ventrally. Female worms are larger, 20 to $49 \mathrm{~cm}$ in length and 3 to 6 $\mathrm{mm}$ in width. Eggs released by the females are passed with host faeces. Both fertilized and unfertilized eggs are usually detected in faeces and both appear brown in colour. Fertilized eggs are round to oval, 45 to 75 by 35 to $50 \mu \mathrm{m}$ in size, containing a developing embryo. The egg is covered by a thick shell made of four layers. The outermost layer appears rough or irregular on the surface and consists of sticky mucopolysaccharide, contributed from the uterine wall of the parent female worm (Foor, 1967). This layer may be removed from many fertilized eggs, giving them a more or less smooth surface. The otherthree layers are secreted by the embryo; they are composed of an outer thin proteinaceous membrane, a middle protein and chitin layer that provides structural strength, and the innermost ascarocide layer, which consists of protein (25\%) and unsaponifiable lipid (75\%). The ascarocide layer is selectively permeable and is important for the survival of the eggs in various hazardous conditions (Wharton, 1980; Perry and Clark, 1981). The unfertilized eggs are larger and elongated in shape, measuring 60 to 100 by 40 to $60 \mu \mathrm{m}$.

\subsection{Transmission}

\subsubsection{Life cycle}

A detailed life cycle of $A$. lumbricoides has been described by Crompton and Pawlowski (1985) and more recently by the United States Centre for Disease Control (Figure 1) (CDC, 2015). At a temperature of $25-30^{\circ} \mathrm{C}$, high humidity and adequate oxygen supply, fertilized eggs released in the environment moult once and embryonate in 15-35 days to become infective.

The infective egg contains a second stage larva which measures 50-70 x 40-50 $\mu \mathrm{m}$ within the egg shell. Infection occurs by ingesting infective eggs with contaminated food materials and/ or soil. The eggs hatch in the jejunum into larvae within a few hours of being swallowed. The larvae penetrate the intestinal mucosa and migrate via the portal vessels and the lymphatic system into the liver in 2-8 days. The larvae at this stage, in experimentally infected rats, measure $258 \times 14 \mu \mathrm{m}$. From there they are carried through the heart to the lungs. They penetrate the capillary walls and enter the lung alveoli where they measure $564 \mathrm{x} 28 \mu \mathrm{m}$. 
They spend about ten days in the lungs when they moult twice to the fourth stage larvae and grow to a size of 1700-2000 $\mu \mathrm{m}$. Then they are coughed up the bronchi and trachea to the pharynx from where they are swallowed. The larvae pass down the oesophagus and through the stomach to the small intestine. On arrival in the small intestine they carry out the fourth and final moult and then form immature adults. The worms mature to adult males and females in 14-20 days and copulation takes place between male and female worms (Shoff, 2015). Fertilized female worms start releasing eggs about 70 days after swallowing infective eggs. A fertilized female worm releases about
200,000 eggs per day and adult worms survive for one to two years in the human host. Majority (about 87\%) of the adult worms reside in the jejunum. The eggs released in the intestine are discharged with the host faeces. The fertilized eggs are very resistant to various harsh environmental conditions, are persistent in the environment and can remain viable in the soil for up to six years (Asaolu et al., 2002a). Due to the microscopic size of the eggs, they can be carried in the wind in dry dust from where they can settle on and contaminate various objects in the human environment.

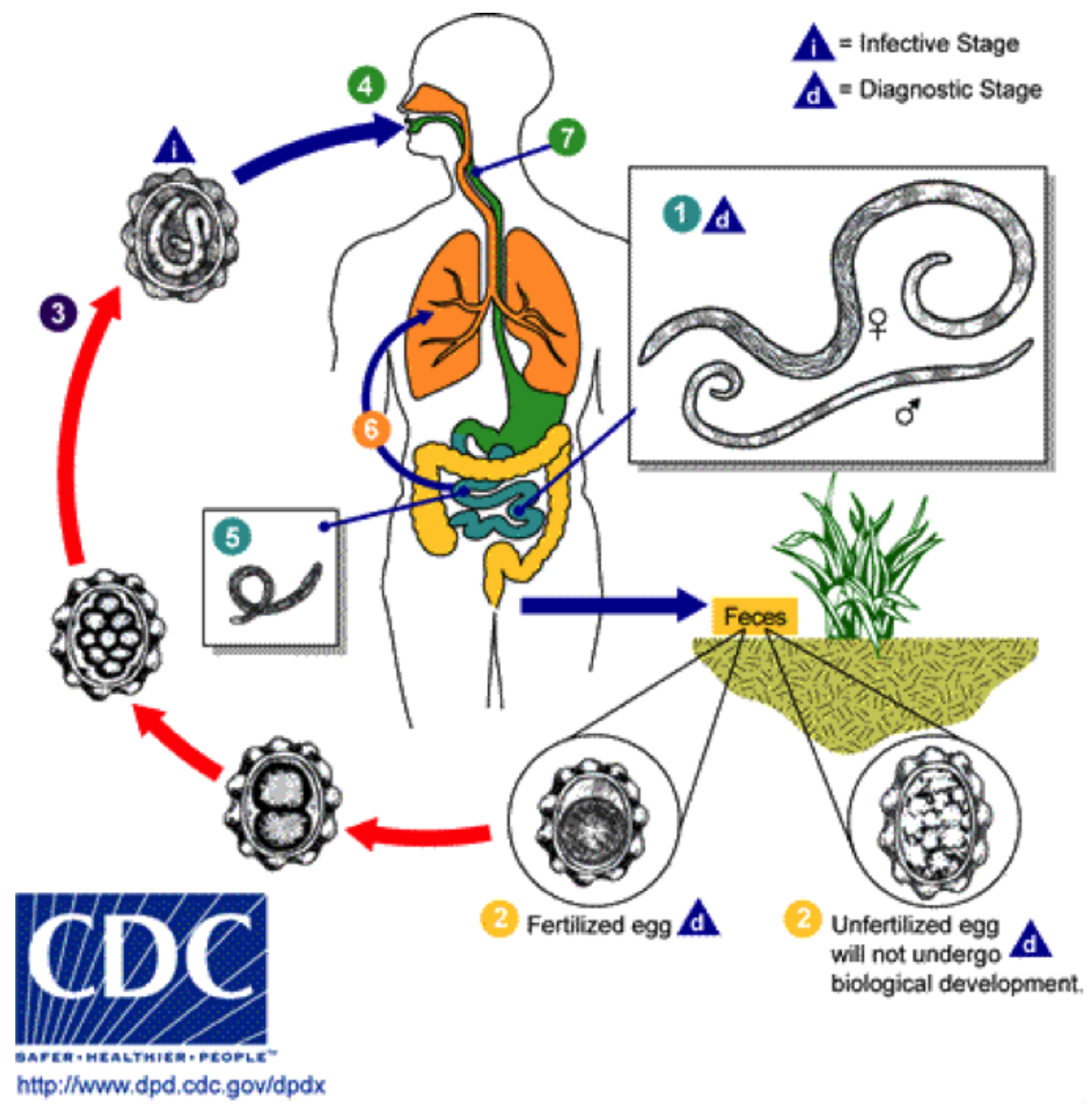

Figure 1. Life Cycle of Ascaris lumbricoides (Adult worms [1]. live in the lumen of the small intestine. A female may produce approximately 200,000 eggs per day, which are passed with the feces [2]. Unfertilized eggs may be ingested but are not infective. Fertile eggs embryonate and become infective after 18 days to several weeks [3], depending on the environmental conditions (optimum: moist, warm, shaded soil). After infective eggs are swallowed [4], the larvae hatch [5], invade the intestinal mucosa, and are carried via the portal, then systemic circulation to the lungs [6]. The larvae mature further in the lungs (10 to 14 days), penetrate the alveolar walls, ascend the bronchial tree to the throat, and are swallowed [7]. Upon reaching the small intestine, they develop into adult worms [1]. Between 2 and 3 months are required from ingestion of the infective eggs to oviposition by the adult female. Adult worms can live 1 to 2 years. (Source: Centers for Disease Control and Prevention (CDC, 2015))

\subsubsection{Routes of transmission}

Transmission of Ascaris lumbricoides is through the faecal-oral route, by the ingestion of the infective eggs from soiled hands and food contaminated with human faeces or unprocessed sludge or biosolids taken from sewage treatment systems where the ova accumulate. Both fertilized and unfertilized eggs are released with faeces. Unfertilized eggs do not develop further and are not infective. To become infective, the fertilized eggs must first develop and embryonate outside the host body in soil (or sludge) in warm and moist conditions to the first stage larva and moult once to form a second stage larva within the egg shell. Eggs embryonate in 15-35 days to become 
infective in the environment.

In highly endemic areas, with poor hygiene facility and behaviour, and where the human environment is contaminated with human wastes, Ascaris eggs can be spread from where they are deposited on the soil on the body of cockroaches, houseflies and other corprophagous insects, or by the wind in dry dust. Ascaris eggs have been found to contaminate various domestic objects and public sites such as coins, paper money, door handles, chopping board, fingers, fruits, vegetables, children's play pens and household furniture. The practice of using night soil (human faeces) as fertilizer or untreated wastewater in irrigation also leads to heavy contamination of the soil and vegetables with Ascaris eggs and infective stages of other gastrointestinal pathogens. In a study conducted by Amahmid et al. (1999) in Marrakech, Morocco, it was shown that crops irrigated with raw wastewater contained Ascaris eggs in the following concentrations per $\mathrm{kg}$ of fresh potatoes (0.18), turnip (0.27), coriander (2.7), mint (4.63), carrots (0.7) and raddish (1.64) while crops irrigated with treated wastewater and freshwater were free from contamination. Section 3 of this write-up gives a detailed account of treatments required to inactivate Ascaris ova in different media. Hence geophagy (ingestion of soil) and poor food and hand hygiene expose people to ingestion of infective Ascaris eggs. Ignorance about the source of infection, lack of potable water supply and inadequate or lack of facility for proper human waste disposal are the major factors contributing to the spread and sustenance of transmission of the worm in most endemic areas.

\subsubsection{Intermediate hosts and reservoirs}

Ascaris lumbricoides has a direct life cycle and thus has no intermediate hosts. The worm is highly host specific and humans are the major reservoir of infection for the worm.

\subsubsection{Incubation period}

The prepatent period, that is, time between the ingestion of the worm's eggs to detection of eggs in host faeces, is 67-76 days. A fertilized female worm produces about 200,000 eggs per day (although the number fluctuates) during a life span of 1-2 years.

\subsection{Population and Individual Control Measures}

\subsubsection{Medical treatment options}

The medications recommended for treatment by the WHO are albendazole, mebendazole, levamisole and pyrantel pamoate (WHO, 2006a, 2011a, 2011b). Other effective drugs include piperazine and nitazoxanide. Albendazole, also a benzimidazole carbamate, is supplied in tablets of $200 \mathrm{mg}$ albendazole and as suspension of $20 \mathrm{mg}$ albendazole/ml. It is administered as a single dose of 400 $\mathrm{mg}$ (2 tablets or $20 \mathrm{ml}$ suspension) to both adults and children above the age of 2 years. Mebendazole, a benzimidazole derivative, kills the worms in the intestine leading to their expulsion within 24 hours of drug administration. Mebendazole is available in oral tablets, each containing $100 \mathrm{mg}$ mebendazole and in suspension containing $20 \mathrm{mg}$ mebendazole/ml. Mebendazole and albendazole should not be given during pregnancy because of possible teratogenic effects.

Materials from local herbs, as plant-based anthelminthic, have also been employed in some countries as alternative treatment of ascariasis. The plants from which the active antihelminthic agents are derived include Prunus mune, Asarum heterotropoides, Zingiber officinale, Coptic chinensis, Angelica sinensis, Phellodendron amurense, Cinnamomum cassia, Panax qinseng and Zanthoxylum bongeanum (Li et al., 1991; Lu, 1992; Xianmin et al., 1999; Yi, 1984). In Madagascar, four local herbs found to be effective in the treatment of ascariasis are Physcalis pemviana, Melia azedaracia, Chenopodium ambrosiodes and Psiadia salviaefolia (Kightlinger et al., 1996). Epazote, an annual plant called Chenopodium ambrosioides, is used as herbal remedy for intestinal worms including ascariasis in South and Central America (Taylor, 2005). Epazote can cause vomiting, dizziness, weakness and convulsions and respiratory and cardiac problems and can be fatal. It is contraindicated in pregnant women because of its toxicity and possible damage it could do to the unborn baby.

Chemoprophylactic measures, by the use of drugs of proven efficacy and safety have been found to be more rapid and more effective in reducing morbidity. In 2001, the World Health Organization endorsed preventive chemotherapy (PCT) as the global strategy to control soiltransmitted helminths (STHs) (WHO, 2006a). The key component of this strategy is regular administration of anthelminthic drugs to at risk groups such as school-aged children, women of reproductive age, and adults in high risk occupations like night soil reuse, farming and others which expose people frequently to contact with soil. The use of chemotherapy for the control of STHs is approached in three ways; mass chemotherapy, group-targeted chemotherapy and treatment of individual cases. The type of chemotherapy control assigned to a community is decided after a survey of the geographical distribution of the prevalence and intensity of infection in that community.

Mass chemotherapy involves treatment of every eligible and willing members of a population at risk without a laboratory diagnosis. Mass treatment has been adjudged to be more economical than the other approaches in that the cost of technical skill and equipment for diagnostic procedure is saved. Mass chemotherapy has been reported as the most effective and has been recommended where more than $20 \%$ of the population is affected, treating everyone at regular interval due to reoccurring infections (Albonico et al., 1995; Hlaing et al.1987; Hagel and Guisti, 2010; Dold and Holland, 2011; Jia et al. 2012).

Group-targeted chemotherapy is directed at specific groups of the population who carry the greatest burden of infection, are at higher risk of morbidity and also the greatest source of contamination of the environment with infective eggs. For STHs, the targeted group usually comprises the school-aged children, except in areas of extreme endemicity where all ages are uniformly infected 
(Albonico et al., 1996, WHO, 1987). It has been established that in targeted chemotherapy, significant reductions in prevalence and worm burden are achieved not only in the targeted group but also in the untreated segment of the population. This is attributable to the overall reduction in contamination of the environment with infective stages of the parasites with a resultant decrease in exposure of the whole community to infection (Bundy et al., 1990; Asaolu et al., 1991; Albonico et al, 1996).

In situations where there is no organized control programme, individuals may take anthelminthic drugs periodically as a prophylactic measure. Individuals who present with symptoms of infection can be diagnosed at the hospital, where the facility is available, and treated. This approach is useful in identifying and treating individuals carrying heavy worm burden or suffering from a severe manifestation. Hence hospital based individual treatments have been suggested as a possible approach to reducing morbidity due to ascariasis in a community (Asaolu et al., 1991).

\subsubsection{Vaccines}

Humans make antibodies (predominantly IgE) in response to Ascaris antigens and infection and the response is believed to confer some immunity. Although several efforts have been made to develop vaccines for effective protection against ascariasis infection, none has proved effective (Hagel and Guisti, 2010). Future research may lead to the development of vaccines that will permit better control and management of the parasite.

\subsubsection{Hygiene measures}

It has been emphasized that preventive chemotherapy (WHO, 2006a) should be applied together with hygiene measures, without which reinfection is inevitable. Hygiene measure against $A$. lumbricoides is through improved access to sanitation. This includes safe disposal of human excreta (Ziegelbauer et al., 2012) by the use of properly functioning toilets or latrines by all community members (Dold and Holland, 2011), and when wastewater is produced, its proper treatment and disposal especially the sludge. It also requires provision of safe and adequate water supply for personal and domestic hygiene (Asaolu and Ofoezie, 2003). Personal hygiene includes washing of the hands before eating and after visiting the toilet. Domestic hygiene requires water to keep food, utensils and home clean (Fung and Cairncross, 2009). Studies in some communities in Iran (Zarga and Khuroo, 1990) have shown positive impacts of the combination of water supplies and excretal disposal on the prevalence and intensity of infection of ascariasis. In St. Lucia, West Indies, prevalence of $A$. lumbricoides fell by $31 \%$ among a group of children with household water and latrine compared with a control group without such facilities (Henry, 1981).

\subsection{Environmental Occurrence and Persistence 2.1 Detection Methods}

According to Collender et al. (2015), quantifying environmental contamination with Ascaris eggs poses major technical challenges to effective monitoring of control programmes. Methods are, therefore, needed that are efficient and sensitive enough to detect low but epidemiologically relevant concentrations in different environmental media and cost effective enough to be deployed in low resource settings where the impact of ascariasis is high (Collender et al., 2015). A systematic review of the literature shows that there are several methods available for assessing the occurrence and intensity of Ascaris ova in different environmental media such as water including surface water, drinking water and seawater; soil including night soil, sewage, sludge, biosolids and faecal materials.

The commonest of the methods are based on flotation, sedimentation, concentration and microscopic examinations. Table 2 presents the list of the most commonly used methods, their sensitivities and power of prevalence estimate of Ascaris ova in faeces. Also presented in the table are the sensitivity and prevalence estimates of different combinations of the methods. Unfortunately, information on the specificity and predictive values of the methods are either too scanty or non-existing. According to Goodman et al. (2007) whom presented the most comprehensive data on sensitivity, the most sensitive single method was sedimentation (91.7\%) while sedimentation and Kato Katz gave the most sensitive combination (100\%). 
Table 2: Prevalence estimates of comparing different methods used to quantify Ascaris lumbricoides eggs in stool

\begin{tabular}{|c|c|c|}
\hline Method & $\begin{array}{c}\text { Prevalence }^{\mathrm{a}} \\
\% \\
\text { (Range) }\end{array}$ & $\begin{array}{c}\text { Sensitivity }^{b} \\
(\%)\end{array}$ \\
\hline Kato Katz $(\mathrm{KK})^{\mathrm{c}}$ & $\begin{array}{c}10.2 \\
\text { (7.1 to } 13.3)\end{array}$ & 77.1 \\
\hline Modified Wisconsin (MW) & $\begin{array}{c}9.1 \\
(6.1 \text { to } 12.1)\end{array}$ & 68.8 \\
\hline Sedimentation (S) & $\begin{array}{c}12.1 \\
\text { (8.8 to } 15.5)\end{array}$ & 91.7 \\
\hline $\begin{array}{c}\text { Formol ethyl } \\
\text { acetate }(\mathrm{FEA})^{\mathrm{c}}\end{array}$ & $\begin{array}{c}8.3^{\mathrm{c}} \\
(5.4 \text { to } 11.1)\end{array}$ & $62.5^{c}$ \\
\hline $\begin{array}{l}\text { Modified formol ethyl } \\
\text { acetate (MFEA) }\end{array}$ & $\begin{array}{c}9.1 \\
(6.1 \text { to } 12.1)\end{array}$ & 68.8 \\
\hline $\mathrm{KK}+\mathrm{MW}$ & $\begin{array}{c}10.5 \\
(7.3 \text { to } 13.6)\end{array}$ & 79.2 \\
\hline $\mathrm{KK}+\mathrm{S}$ & $\begin{array}{c}13.2 \\
(9.7 \text { to } 16.7)\end{array}$ & 100 \\
\hline $\mathrm{KK}+\mathrm{FEA}$ & $\begin{array}{c}11.0 \\
\text { (7.8 to } 14.3)\end{array}$ & 83.3 \\
\hline $\mathrm{KK}+\mathrm{MFEA}$ & $\begin{array}{c}10.7 \\
\text { (7.5 to } 13.9)\end{array}$ & 81.1 \\
\hline $\mathrm{MW}+\mathrm{S}$ & $\begin{array}{c}12.7 \\
(9.2 \text { to } 16.1)\end{array}$ & 95.8 \\
\hline $\mathrm{MW}+\mathrm{FEA}$ & $\begin{array}{c}10.2 \\
\text { (7.1 to } 13.3)\end{array}$ & 77.1 \\
\hline $\mathrm{MW}+\mathrm{MFEA}$ & $\begin{array}{c}9.9 \\
\text { (6.8 to 13.0) }\end{array}$ & 75.0 \\
\hline $\mathrm{S}+\mathrm{FEA}$ & $\begin{array}{c}12.1 \\
(8.8 \text { to } 15.5)\end{array}$ & 91.7 \\
\hline $\mathrm{S}+\mathrm{MFEA}$ & $\begin{array}{c}12.4 \\
\text { (9.0 to } 15.8)\end{array}$ & 93.8 \\
\hline $\mathrm{FEA}+\mathrm{MFEA}$ & $\begin{array}{c}10.2 \\
\text { (7.1 to } 13.3)\end{array}$ & 77.1 \\
\hline
\end{tabular}

${ }^{a}$ Percentage of ova found in feces by a comparative study (Goodman et al., 2007); ${ }^{b}$ Probability of accurate positive diagnosis (Goodman et al., 2007); 'Periago et al. (2015) study comparing Kato Katz (KK) and Formol ethyl acetate (FEA)

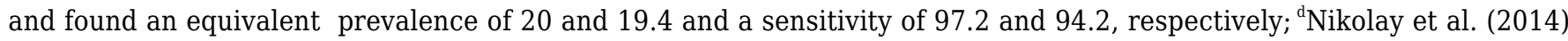
compared sensitivities of: Direct microscopy, Kato Katz (KK), FLOTAC, Mini FLOTAC, Formol ethyl acetate (FEA), and McMaster and found 52.1, range of 63.8 to 70.4, 79.7, 75.5, 56.9, and 61.1, respectively

Table 2b. Sensitivity of different methods used to quantify Ascaris lumbricoides eggs in stool

\begin{tabular}{|c|c|c|c|c|c|}
\hline \multirow[b]{2}{*}{ Method } & \multicolumn{2}{|c|}{ Prevalence (\%)(Range) } & \multicolumn{3}{|c|}{ Sensitivity $\left.{ }^{\mathrm{a}} \%\right)$} \\
\hline & $\begin{array}{c}\text { Goodman } \\
\text { et al., } \\
2007\end{array}$ & $\begin{array}{c}\text { Periago } \\
\text { et al., } \\
2015\end{array}$ & $\begin{array}{c}\text { Goodman } \\
\text { et al., } \\
2007\end{array}$ & $\begin{array}{c}\text { Periago } \\
\text { et al., } \\
2015\end{array}$ & $\begin{array}{l}\text { Nikolay } \\
\text { et al., } \\
2014\end{array}$ \\
\hline Direct microscopy & $\mathrm{NR}^{\mathrm{b}}$ & NR & NR & NR & 52.1 \\
\hline Kato Katz (KK) & $\begin{array}{c}10.2 \\
(7.1 \text { to } \\
13.3)\end{array}$ & 20 & 77.1 & 97.3 & $\begin{array}{c}63.8 \text { to } \\
70.4\end{array}$ \\
\hline $\begin{array}{l}\text { Modified Wisconsin } \\
\text { (MW) }\end{array}$ & $\begin{array}{c}9.1 \\
\text { (6.1 to } \\
12.1)\end{array}$ & NR & 68.8 & NR & NR \\
\hline
\end{tabular}




\begin{tabular}{|c|c|c|c|c|c|}
\hline \multirow[b]{2}{*}{ Method } & \multicolumn{2}{|c|}{ Prevalence (\%)(Range) } & \multicolumn{3}{|c|}{ Sensitivity ${ }^{a}(\%)$} \\
\hline & $\begin{array}{c}\text { Goodman } \\
\text { et al., } 2007\end{array}$ & $\begin{array}{c}\text { Periago } \\
\text { et al., } 2015\end{array}$ & $\begin{array}{l}\text { Goodman } \\
\text { et al., } 2007\end{array}$ & $\begin{array}{c}\text { Periago } \\
\text { et al., } 2015\end{array}$ & $\begin{array}{c}\text { Nikolay } \\
\text { et al., } 2014\end{array}$ \\
\hline Sedimentation (S) & $\begin{array}{c}12.1 \\
\text { (8.8 to } 15.5)\end{array}$ & NR & 91.7 & NR & NR \\
\hline FLOTAC & NR & NR & NR & NR & 79.7 \\
\hline Mini FLOTAC & NR & NR & NR & NR & 75.5 \\
\hline $\begin{array}{l}\text { Formol ethyl } \\
\text { acetate (FEA) }\end{array}$ & $\begin{array}{c}8.3 \\
\text { (5.4 to } 11.1)\end{array}$ & 19.4 & 62.5 & 94.2 & 56.9 \\
\hline $\begin{array}{l}\text { Modified formol } \\
\text { ethyl acetate (MFEA) }\end{array}$ & $\begin{array}{c}9.1 \\
\text { (6.1 to } 12.1 \text { ) }\end{array}$ & NR & 68.8 & NR & NR \\
\hline $\mathrm{KK}+\mathrm{MW}$ & $\begin{array}{l}10.5 \\
(7.3 \text { to } \\
13.6)\end{array}$ & NR & 79.2 & NR & NR \\
\hline $\mathrm{KK}+\mathrm{S}$ & $\begin{array}{c}13.2 \\
\text { (9.7 to } 16.7)\end{array}$ & NR & 100 & NR & NR \\
\hline $\mathrm{KK}+\mathrm{FEA}$ & $\begin{array}{c}11 \\
\text { (7.8 to } 14.3 \text { ) }\end{array}$ & NR & 83.3 & NR & NR \\
\hline $\mathrm{KK}+\mathrm{MFEA}$ & $\begin{array}{l}10.7 \\
(7.5 \text { to } \\
13.9)\end{array}$ & NR & 81.1 & NR & NR \\
\hline $\mathrm{MW}+\mathrm{S}$ & $\begin{array}{l}12.7 \\
(9.2 \text { to } \\
16.1)\end{array}$ & NR & 95.8 & NR & NR \\
\hline MW+FEA & $\begin{array}{c}10.2 \\
\text { (7.1to 13.3) }\end{array}$ & NR & 77.1 & NR & NR \\
\hline $\mathrm{MW}+\mathrm{MFEA}$ & $\begin{array}{c}9.9 \\
(6.8 \text { to13.0) }\end{array}$ & NR & 75 & NR & NR \\
\hline $\mathrm{S}+\mathrm{FEA}$ & $\begin{array}{c}12.1 \\
\text { (8.8 to } 15.5 \text { ) }\end{array}$ & NR & 91.7 & NR & NR \\
\hline $\mathrm{S}+\mathrm{MFEA}$ & $\begin{array}{l}12.4 \\
(9.0 \text { to } \\
15.8)\end{array}$ & NR & 93.8 & NR & NR \\
\hline FEA + MFEA & $\begin{array}{l}10.2 \\
(7.1 \text { to } \\
13.3)\end{array}$ & NR & 77.1 & NR & NR \\
\hline McMaster & NR & NR & NR & NR & 61.1 \\
\hline
\end{tabular}

${ }^{a}$ Probability of accurate positive diagnosis; ${ }^{\text {bNR: Not Reported }}$

However, though data presented by other workers (Nikolay et al., 2014; Periago et al., 2015) were comparatively scanty, it is obvious that both prevalence estimates and sensitivity of each method varied substantially from one investigation to another. Also sensitivity appeared to increase with increasing prevalence estimate, although data presented may not sufficiently support this conclusion. Table 3 gives the outcome of McMaster method using different protocols to assess capacity to recover Ascaris eggs in a given medium. The lesson here is that outcome of even the best method may depend on the actual protocol selected. Using the mean recovery rate, Jeandron et al. (2014) showed that McMaster was over 33\% better than FLOTAC. the performance of McMaster varied substantially depending on the type of tubes, pipettes and detergents used. Its worst performance (33.4\% recovery rate) was recorded with the use of Falcon tubes and coated glass pipettes. Conversely, it performed best (89.4\% mean recovery rate) when detergent 7X 1\% was used. Besides the egg recovery efficiency, the challenge remains notably in environmental samples that are not too clean, for instance sludge, biosolids and wastewater. In such media, proper identification of eggs in a mixture of particles is very difficult under a microscope (Maya et al., 2006). 
Table 3: Mean recovery rate of Asaris ova on hand by different methods (Source: Jeandron et al., 2014)

\begin{tabular}{|c|c|}
\hline Method & Mean egg recovery rate (\%) (95 \\
\hline $\begin{array}{l}\text { FLOTAC (basic } \\
\text { method) }\end{array}$ & $43.3(26.4$ to 60.1$)$ \\
\hline McMaster & 64.8 (52.6 to 77.1$)$ \\
\hline \multicolumn{2}{|l|}{ McMaster with: } \\
\hline $\begin{array}{l}\text { Falcon tubes NC } \\
\text { and glass } \\
\text { pipettes NC }\end{array}$ & $58.4(33.2$ to 83.6$)$ \\
\hline $\begin{array}{l}\text { Falcon tubes NC } \\
\text { and glass } \\
\text { pipettes CC }\end{array}$ & $57.0(30.7$ to 83.2$)$ \\
\hline $\begin{array}{l}\text { Falcon tubes C } \\
\text { and glass } \\
\text { pipettes C }\end{array}$ & 33.4 ( 0 to 74.0$)$ \\
\hline $\begin{array}{l}\text { Falcon tubes C } \\
\text { and plastic } \\
\text { pipettes NC }\end{array}$ & $37.3(0$ to 86.5$)$ \\
\hline $\begin{array}{l}\text { Falcon tubes C } \\
\text { and glass } \\
\text { pipettes NC }\end{array}$ & 35.5 (0 to 95.4$)$ \\
\hline $\begin{array}{l}\text { McMaster and } \\
\text { various } \\
\text { detergents viz: } \\
\text { 7X 1\% }\end{array}$ & $89.4(67.1$ to 100$)$ \\
\hline Tween $800.1 \%$ & 58.5 (32.5 to 85.5$)$ \\
\hline $\begin{array}{l}\text { Benzethonium } \\
\text { chloride } 0.1 \%\end{array}$ & 86.7 (73.7 to 99.8$)$ \\
\hline $\begin{array}{l}\text { Cetylpyridinium } \\
\text { chloride } 0.1 \%\end{array}$ & $84.2(65.7$ to 100$)$ \\
\hline $\begin{array}{l}\text { Deionized water } \\
\text { (control) }\end{array}$ & $74.0(67.3$ to 80.7$)$ \\
\hline
\end{tabular}

2.1.1 Methods used to assess viability of Ascaris ova in different environmental media

The increasing use of sewage sludge and biosolids in agriculture has increased the number of Ascaris ova in the environment (Simonart et al., 2003). Besides, the resilience and hardiness of Ascaris ova exacerbate rather than mitigate the problem. Subsequently, ascariasis is now a major risk to public health especially in the tropical areas where poverty and environmental conditions that favour its transmission also exist. As already stated, breaking transmission requires that contaminated environmental media are identified and eggs inactivated as will be described in the next section. However, presence of Ascaris ova is not always an indication of potential transmission unless the eggs are confirmed to be viable. This is because non-viable eggs cannot transmit disease and treating nonviable eggs is wasteful in terms of resources and efforts. It is therefore important to identify methods that can determine not only the presence of Ascaris eggs in a medium but also discriminate between viable and nonviable status. The importance of this is not farfetched. Presence of viable eggs in a sample is a clear indication of risk to public and/or livestock health and the use of biosolids and compost manure in agriculture increases this risk.

There are currently several methods available for the assessment and enumeration of viable Ascaris eggs in several media (Table 4). These methods can broadly be divided into two major groups; (i) methods based on optical microscopy and (ii) methods based on molecular technologies. The microscopy based methods are further divided into those that require the use of vital dyes and those that do not require staining. The first group include the Tulane method developed by Reimers et al. (1981) and its modified version the Yanko method. Others are the Gaspard, the US EPA and the Victorian methods. The Triple flotation and the Norwegian methods were modifications of the US EPA method that incorporated staining technology. The principle of staining is based on the fact that usually live and dead eggs react differently to vital dyes and give out different colours. The cell membrane of live cells usually absorbs dyes, while membranes of dead cells are impermeable to dyes. For instance, using the LIVE/DEAD BacLight Bacterial Viability kit, Dabrowska et al. (2014) 
reported that viable eggs stained red while dead eggs stained green. The most prominent molecular technique is the quantitative polymerase chain reaction (rPCR) developed by Pecson et al. (2006). This method is based on the theoretical concept that first internally transcribed spacer (ITS-1) region of ribosomal DNA (rDNA) and rRNA levels increase proportionally with the number of cells in an Ascaris egg. Thus, quantitative estimate of ITS- 1 level is a good index for detecting non-viable, viable and larvated eggs.

The major difference between the microscopy methods is in the solutions used in the different steps of desorption, flotation, extraction and incubation. Another difference is that some perform the extraction step after the incubation of eggs to induce hatching of embryonated eggs, such as the Tulane method and its modifications (Reimers et al., 1981; Gaspard et al., 1996). USEPA method is, however, the most commonly and widely used although there are complaints that it is too tedious, time consuming and involves too many steps, including filtration and incubation that may last for weeks (Simonart et al., 2003). The general consensus is that among the incubation based methods, none combines both speed and sensitivity in the detection of viable Ascaris eggs (Vieira da Rocha et al., 2016).
Raynal et al. (2012) reported that the recent application of polymerase chain reaction (PCR) could for the first time provide a procedure that is both fast and reliable. However, Choi et al. (2007) reported that while this may be true, conventional PCR can only identify presence or absence of particular Ascaris species in a sample, but cannot quantify their levels. This limitation has now been corrected by the development of incubated quantitative PCR (qPCR) which is capable of quantifying the levels of viable eggs in samples (Pecson et al., 2006; Dabrowska et al., 2014). In spite of this, the prevalence of false positives is still high and efforts are being made to provide an effective tool that is both effective and sensitive (Vieira da Rocha et al., 2016). The Reverse Transcriptase-PCR (RT-PCR) which uses RNA rather than DNA has been suggested as an option against this weakness.

However, Rocha (2015) argued that even when this is true, there are no technologies available for relating the quantity of RNA in a sample to the number of viable Ascaris eggs. Thus, while the potential of RT-PCR to reduce false positive in samples is high, its application may have to wait till a procedure is found that relates the quantity of RNA in sample to the number of viable Ascaris eggs.

Table 4a: Major methods used for assessing viability of Ascaris ova in different environmental media

\begin{tabular}{|c|c|c|c|c|c|}
\hline Method & Surfactant & Floatation liquid & Extraction & Incubation & Reference \\
\hline Tulane & Limbro 7X & $\mathrm{MgSO}_{4}$ & $\begin{array}{l}\text { Sieving p10\% } \\
\mathrm{NaClO}\end{array}$ & $\begin{array}{c}\text { Formalin } \\
0.5 \%\end{array}$ & $\begin{array}{l}\text { Reimers et } \\
\text { al., 1981; } \\
\text { Bowman } \\
\text { et al., } \\
2003\end{array}$ \\
\hline Yanko & $\begin{array}{c}\text { Hot } \\
\text { tapwater }\end{array}$ & $\mathrm{ZnSO}_{4}$ & Acid alcohol & $\mathrm{H}_{2} \mathrm{SO}_{4} 0.1 \mathrm{~N}$ & $\begin{array}{c}\text { Yanko, } \\
1987\end{array}$ \\
\hline Gaspard & $0.01 \%$ SDS & $\mathrm{NaCL}$ & $\begin{array}{l}\text { Ultrasonication } \\
\text { p NaClO }\end{array}$ & $\begin{array}{l}\text { Deionized } \\
\text { water }\end{array}$ & $\begin{array}{l}\text { Gaspard et } \\
\text { al., } 1996\end{array}$ \\
\hline USEPA & Limbro 7X & $\mathrm{MgSO}_{4}$ & Sieving & $\mathrm{H}_{2} \mathrm{SO}_{4} 0.1 \mathrm{~N}$ & $\begin{array}{l}\text { USEPA, } \\
2003\end{array}$ \\
\hline $\begin{array}{l}\text { De } \\
\text { Victorica } \\
\text { and } \\
\text { Galvan }\end{array}$ & $\mathrm{NaCl} .85 \%$ & $\mathrm{ZnSO}_{4} / \mathrm{MgSO}_{4}$ & $\begin{array}{l}\text { Membrane } \\
\text { filter }\end{array}$ & None & $\begin{array}{c}\text { de } \\
\text { Victorica } \\
\text { and } \\
\text { Galvan, } \\
\text { 2003; } \\
\text { Pecson et } \\
\text { al., 2006 }\end{array}$ \\
\hline
\end{tabular}


Table 4b: Major methods used for enumerating the viability of Ascaris ova in different environmental media

\begin{tabular}{|c|c|c|c|c|}
\hline Method & Floatation liquid & Microscopy & Viability classification* & Reference \\
\hline $\begin{array}{l}\text { EPA } \\
\text { Modified }^{\mathrm{a}, \mathrm{b}}\end{array}$ & $\mathrm{NaNO}_{3}$ & Yes & Embryonated & $\begin{array}{l}\text { USEPA, } \\
\text { 1999; } \\
\text { Simonart } \\
\text { et al., } \\
2003\end{array}$ \\
\hline $\begin{array}{l}\text { Triple } \\
\text { Flotation }^{\mathrm{a}}\end{array}$ & $\mathrm{ZnSO}_{4}$ & Yes & MTT dye (blue) & $\begin{array}{l}\text { Simonart } \\
\text { et al., } \\
2003\end{array}$ \\
\hline $\begin{array}{l}\text { Norwegian } \\
\text { Method }^{\mathrm{a}}\end{array}$ & Sucrose & Yes & Embryonated & $\begin{array}{l}\text { Simonart } \\
\text { et al., } \\
2003\end{array}$ \\
\hline $\begin{array}{l}\text { Quantitative } \\
\text { Polymerase } \\
\text { Chain } \\
\text { Reaction } \\
\text { (qPCR) }\end{array}$ & ????? & Yes & Stain green & $\begin{array}{c}\text { Dabrowska } \\
\text { et al., } \\
2014\end{array}$ \\
\hline
\end{tabular}

\subsection{Data on Occurrence in the Environment}

\subsubsection{Occurrence in excreta in the environment}

There are many sources of human excreta in the environment. These include but not limited to open defaecation, evacuation of pit latrines, compost latrines and vault latrines (Esrey, 1998). Consequently, Ascaris ova could be more widespread in the environment than imagined (Table 5). The table shows clearly that Ascaris ova occurred in all environmental media investigated at varying prevalence. For instance, prevalence of Ascaris ova in soil ranged from $8.8 \%$ at Umuji in Nigeria (Chukwuma et al., 2009) to $84.4 \%$ in Turkey (Ulukanligil et al., 2001). The corresponding prevalence range for other media were for faecal matter $29.6 \%$ in Nigeria (Odu et al., 2013) to $88.5 \%$ in Turkey (Ulukanligil et al., 2001); water samples 5.0\% in Pesing Polgar (Subahar and Sutanto, 2008) to $60.8 \%$ in Turkey (Ulukanligil et al., 2001). Other media where Ascaris ova were recorded included vegetables (14\%), manure $30 \%$ (at the middle heap) to $88.0 \%$ (at the bottom heap), human nails (65\%) and hands (60\%).

Table 5. Prevalence of Ascaris ova in different media in Nigeria and Turkey

\begin{tabular}{|c|c|c|c|}
\hline Area & $\begin{array}{c}\text { In Soil } \\
\text { Percent Positive } \\
\text { (\# of Samples) }\end{array}$ & $\begin{array}{c}\text { In Faecal Matter } \\
\text { Percent Positive } \\
\text { (\# of Samples) }\end{array}$ & Reference \\
\hline \multicolumn{4}{|c|}{ Nigeria } \\
\hline Umuji & $\begin{array}{c}8.8 \\
(7 / 80)\end{array}$ & $\begin{array}{c}50 \\
(40 / 80)\end{array}$ & Chukwuma et al., 2009 \\
\hline Umuogbuefi & $\begin{array}{c}30 \\
(18 / 60)\end{array}$ & $\begin{array}{c}50 \\
(40 / 80)\end{array}$ & Chukwuma et al., 2009 \\
\hline Obuno & $\begin{array}{c}27.5 \\
(22 / 80)\end{array}$ & $\begin{array}{c}65 \\
(39 / 60)\end{array}$ & Chukwuma et al., 2009 \\
\hline Choba & $\mathrm{NR}^{\mathrm{a}}$ & $\begin{array}{c}29.6 \\
(8 / 27)\end{array}$ & Odu et al., 2013 \\
\hline Rumuolumeni & NR & $\begin{array}{c}70.4 \\
(19 / 27)\end{array}$ & Odu et al., 2013 \\
\hline Nwofe-Agbaje & $\begin{array}{c}30 \\
(18 / 60)\end{array}$ & NR & Nwoke et al., 2013 \\
\hline Omu-Ebonyi & $\begin{array}{c}33.3 \\
(20 / 60)\end{array}$ & NR & Nwoke et al., 2013 \\
\hline Ntezi-Abba & $\begin{array}{c}28.3 \\
(17 / 60)\end{array}$ & NR & Nwoke et al., 2013 \\
\hline
\end{tabular}




\begin{tabular}{lccc}
\hline Area & $\begin{array}{c}\text { In Soil } \\
\text { Percent Positive } \\
\text { (\# of Samples) }\end{array}$ & $\begin{array}{c}\text { In Faecal Matter } \\
\text { Percent Positive } \\
\text { (\# of Samples) }\end{array}$ & Reference \\
\hline Umuogharu & 36.7 & NR & Nwoke et al., 2013 \\
Ezzagu & $(22 / 60)$ & NR & Nwoke et al., 2013 \\
& 25 & Turkey & \\
\hline Turkey & $(15 / 60)$ & 88.5 & Ulukanligil et al., 2001
\end{tabular}

${ }^{a}$ NR: Not Reported

\subsubsection{Occurrence in sanitation facilities}

Table 6 presents the prevalence of Ascaris ova in the major sanitation facilities examined in Nigeria and Kenya. Clearly, Ascaris ova occurred in all the facilities recorded in the literature. However, prevalence is higher in the pit latrines and bush defaecation sites than in around water closet. This can be explained partly by the socio-economic divergences of people using each type of latrine and the physico-chemical characteristics of the latrines (Walls, 2015).

Prevalence of viable Ascaris eggs in fresh and old samples of faeces and compost can be assessed by different viability test methods. The various methods tried to compare the capacity of the tools to discriminate among dead eggs, viable eggs and embryonated eggs in fresh and old samples (Table 7). The samples investigated included compost, UV inactivated eggs and faecal sludge.

Table 6. Prevalence of Ascaris ova in different latrine facilities in Nigeria and Kenya

\begin{tabular}{|c|c|c|c|c|c|}
\hline Area & $\begin{array}{c}\text { Water Closet Percent } \\
\text { Positive } \\
\text { (\# of Samples) } \\
\end{array}$ & $\begin{array}{c}\text { Pit Latrine } \\
\text { Percent Positive } \\
\text { (\# of Samples) } \\
\end{array}$ & $\begin{array}{c}\text { Bucket } \\
\text { Percent Positive } \\
\text { (\# of Samples) }\end{array}$ & $\begin{array}{c}\text { Open Defaecation } \\
\text { Percent Positive } \\
\text { (\# of Samples) } \\
\end{array}$ & References \\
\hline \multicolumn{6}{|c|}{$\overline{\text { Kenya }}$} \\
\hline Kenya & $\begin{array}{c}11.7 \\
(17 / 145)\end{array}$ & $\begin{array}{c}11.8 \\
(41 / 347)\end{array}$ & $\begin{array}{c}0 \\
(0 / 1)\end{array}$ & $\begin{array}{l}16.7 \\
(1 / 6)\end{array}$ & $\begin{array}{c}\text { Adoko, } \\
1985\end{array}$ \\
\hline \multicolumn{6}{|c|}{ Nigeria } \\
\hline Imo State & $\begin{array}{c}6.3 \\
(1 / 16)\end{array}$ & $\begin{array}{c}32.3 \\
(70 / 217)\end{array}$ & $\mathrm{NR}^{\mathrm{a}}$ & $\begin{array}{c}29.4 \\
(15 / 51)\end{array}$ & $\begin{array}{c}\text { Odinaka et } \\
\text { al., } 2015\end{array}$ \\
\hline Choba & $\begin{array}{c}10.1 \\
(16 / 158)\end{array}$ & NR & NR & NR & $\begin{array}{l}\text { Odu et al., } \\
2013\end{array}$ \\
\hline Rumuolumeni & $\begin{array}{c}18.3 \\
(15 / 82)\end{array}$ & $\begin{array}{c}26.7 \\
(16 / 60)\end{array}$ & NR & NR & $\begin{array}{l}\text { Odu et al., } \\
2013\end{array}$ \\
\hline Akure & $\begin{array}{c}52.4 \\
(22 / 42)\end{array}$ & $\begin{array}{c}41.9 \\
(44 / 105)\end{array}$ & $\begin{array}{c}53.3 \\
(8 / 15)\end{array}$ & NR & $\begin{array}{l}\text { Dada and } \\
\text { Aruwa, } \\
2015\end{array}$ \\
\hline Akure & $\begin{array}{c}18.8 \\
(6 / 32)\end{array}$ & $\begin{array}{c}72.9 \\
(107 / 148)\end{array}$ & NR & $\begin{array}{c}72.9 \\
(124 / 170)\end{array}$ & Dada, 2016 \\
\hline Zamfara & $\begin{array}{c}1.5 \\
(9 / 600)\end{array}$ & $\begin{array}{c}67.8 \\
(407 / 600)\end{array}$ & NR & $\begin{array}{c}7.7 \\
(46 / 600)\end{array}$ & $\begin{array}{l}\text { Shehu et } \\
\text { al., } 2013\end{array}$ \\
\hline
\end{tabular}

${ }^{a}$ NR: Not Reported 
Table 7. Prevalence of viable Ascaris eggs in fresh and old faecal samples assessed by different viability test methods

\begin{tabular}{|c|c|c|c|c|c|c|}
\hline Area & Matrix & Method & Treatment & $\begin{array}{c}\text { Fresh Samples } \\
\text { Percent Positive (\# of Samples) } \\
\end{array}$ & $\begin{array}{c}10 \text { Day Old Samples } \\
\text { Percent Positive (\# of Samples) }\end{array}$ & Reference \\
\hline Haiti & $\begin{array}{l}\text { Compost } \\
\text { of } \\
\text { faeces }\end{array}$ & $\begin{array}{l}\text { US EPA } \\
\text { method }^{\text {a }}\end{array}$ & Composting & $\begin{array}{c}10.4 \\
(94 / 900)\end{array}$ & $\begin{array}{c}0.46 \\
(14 / 3055)\end{array}$ & $\begin{array}{l}\text { Berendes } \\
\text { et al., } \\
2015\end{array}$ \\
\hline $\begin{array}{l}\text { NY, } \\
\text { USA }\end{array}$ & $\begin{array}{l}\text { Stock } \\
\text { solution }\end{array}$ & $\begin{array}{l}\text { US EPA } \\
\text { method }^{\text {a }}\end{array}$ & UV & $\begin{array}{c}21.8 \\
(44 / 202)\end{array}$ & $\begin{array}{c}11 \\
(23 / 210)\end{array}$ & $\begin{array}{l}\text { Raynal et } \\
\text { al., } 2012\end{array}$ \\
\hline $\begin{array}{l}\text { NY, } \\
\text { USA }\end{array}$ & $\begin{array}{c}\text { Stock } \\
\text { solution }\end{array}$ & $\begin{array}{l}\text { US EPA } \\
\text { method }^{\text {a }}\end{array}$ & $\begin{array}{l}\text { High heat } \\
\left(70^{\circ} \mathrm{C} \text { for }\right. \\
30 \text { s to } 3 \mathrm{~min})\end{array}$ & $\begin{array}{c}0.01 \\
(2 / 275)\end{array}$ & $\begin{array}{c}0 \\
(0 / 258)\end{array}$ & $\begin{array}{l}\text { Raynal et } \\
\text { al., } 2012\end{array}$ \\
\hline $\begin{array}{l}\text { NY, } \\
\text { USA }\end{array}$ & $\begin{array}{l}\text { Stock } \\
\text { solution }\end{array}$ & $\begin{array}{l}\text { US EPA } \\
\text { method }^{\text {a }}\end{array}$ & $\begin{array}{c}\text { Moderate } \\
\text { heat }\left(40^{\circ} \mathrm{C}\right. \\
\text { for } 6 \text { to } 24 \mathrm{~h})\end{array}$ & $\begin{array}{c}0 \\
(0 / 124)\end{array}$ & $\begin{array}{c}0 \\
(0 / 144)\end{array}$ & $\begin{array}{l}\text { Raynal et } \\
\text { al., } 2012\end{array}$ \\
\hline $\begin{array}{l}\text { NY, } \\
\text { USA }\end{array}$ & $\begin{array}{c}\text { Stock } \\
\text { solution }\end{array}$ & $\begin{array}{l}\text { US EPA } \\
\text { method }^{\text {a }}\end{array}$ & $\begin{array}{c}\text { Moderate } \\
\text { heat }\left(40^{\circ} \mathrm{C}\right. \\
\text { with } 2000 \\
\left.\text { mgl- } 1 \mathrm{NH}_{3}-\mathrm{N}\right)\end{array}$ & $\begin{array}{c}0 \\
(0 / 96)\end{array}$ & $\begin{array}{c}0 \\
(0 / 88)\end{array}$ & $\begin{array}{l}\text { Raynal et } \\
\text { al., } 2012\end{array}$ \\
\hline
\end{tabular}

${ }^{a} 94$ viable Ascaris ova found in only fresh untreated compost and none in compost older than 6 weeks; 76 embroyanated ova (infectious) were also found in the fresh untreated compost and none in compost older than 2 weeks

All the methods showed that there are more viable eggs in fresh samples than in old samples. For instance, the US EPA showed that composition of viable eggs in fresh samples could range from $10.4 \%$ in fresh compost to $21.6 \%$ in faecal sludge. In the compost, the method identified $79.8 \%$ of the viable eggs as being embryonated. It is also interesting to note that modified US EPA methods identified more eggs as viable compared with the original method, the most sensitive being modified US EPA method with sieving. Each of the methods identified as viable less eggs in older samples. Although not shown in this table, the number of viable eggs identified by the methods decreased with increasing age of samples. After two weeks, no viable eggs were found in any sample (Raynal et al., 2012; Berendes et al., 2015). Factors which affected the rate and length of viability included temperature, moisture and location of sampling (i.e. centre or side vault). While Berendes et al., (2015) reported that Ascaris eggs at the centre die-off faster than those at the side vaults, they found no significant effect of temperature.

\subsection{Persistence}

Persistence is the period of time a pathogen or its larval stage can survive in the environment under natural conditions. Generally, persistence is affected by climatic conditions chief among which are temperature, moisture content, location characteristics. Table 8a-c presents the reports of various workers in different parts of the world on the persistence of Ascaris ova of different species. Clearly, temperature has an overwhelming effect on the persistence of Ascaris ova in different media. Generally, persistence decreases with increasing temperature (Yadav, 2003; de Faria et al., 2017). This is a clear indication that Ascaris eggs are more likely to survive longer in the temperate environment than in the tropical environment (Katakam et al. (2013). For instance, at temperatures $\leq 20^{\circ} \mathrm{C}$ more than $50 \%$ of Ascaris eggs in various environmental media could survive for a period ranging from 200 to more than 520 days. Liquid slurry appears to have the most protective effect on Ascaris eggs. For an example, while at $5^{\circ} \mathrm{C}$ the T50 and T99 of eggs in raw slurry were less than 300 and 560 days respectively, the corresponding values for eggs in liquid slurry were > 500 and 1000 days respectively (Katakam et al., 2014a). Similar findings were reported by Strauch (1991). The single data on moisture content/relative humidity provided unequivocal evidence that persistence increased with increasing moisture content/relative humidity at constant temperature. There is about a threefold increase in persistence when moisture content was increased from $40 \%$ to $60 \%$, and a whopping 4-5 fold rise in a moisture content increase from $60 \%$ to $80 \%$. Although, a no change in persistence when moisture content was increased from $80 \%$ and $100 \%$ may be interpreted as a tabling effect, such conclusion must be drawn with caution because the researchers simply aborted further observations after 210 days. Besides, a recent investigation in Kwazulu Natal, revealed that under natural conditions Ascaris eggs may persist and remain viable in faecal sludge longer than previously imagined. The researchers actually found large numbers of viable Ascaris eggs in 15 year old sludge that had spent 2 years buried outside the original pit. 
Table 8a. Persistence of Ascaris suum eggs in various slurries

\begin{tabular}{|c|c|c|c|}
\hline Matrix & $\begin{array}{c}\text { Temperature } \\
{ }^{\circ} \mathbf{C}\end{array}$ & $\begin{array}{c}\text { T99 } \\
\text { (Days) } \\
\text { (T50 Days) } \\
\end{array}$ & Reference \\
\hline Raw slurry & 5 & $\begin{array}{c}553 \\
(281)\end{array}$ & Katakam et al., 2014a \\
\hline Raw slurry & 5 & $\begin{array}{c}355 \\
(183)\end{array}$ & Katakam et al., 2014a \\
\hline Liquid slurry & 5 & $\begin{array}{l}1034 \\
(519)\end{array}$ & Katakam et al., 2014a \\
\hline Liquid slurry & 25 & $\begin{array}{c}274 \\
(143)\end{array}$ & Katakam et al., 2014a \\
\hline Dungstead manure & 40 & 63 & Strauch, 1991 \\
\hline Dungstead manure & 50 & 19 & Strauch, 1991 \\
\hline Liquid manure & 8 & 85 & Strauch, 1991 \\
\hline Liquid manure & 18 & 65 & Strauch, 1991 \\
\hline Slurry (Storage pit) & $20+$ & 75 & Strauch, 1991 \\
\hline Slurry (Storage pit) & 26 & 28 & Strauch, 1991 \\
\hline Liquid manure (Storage pit - aerated) & $\mathrm{NR}^{\mathrm{a}}$ & 365 & Strauch, 1991 \\
\hline Pig manure (storage pit - non aerated) & NR & 365 & Strauch, 1991 \\
\hline Sewage sludge (dried) & NR & 1825 & Strauch, 1991 \\
\hline Sewage sludge (storage pit) & NR & 810 & Strauch, 1991 \\
\hline Cattle slurry (aerobic) & 35 to 40 & 14 & Strauch, 1991 \\
\hline Cattle manure (storage pit) & 22 to 27 & 57 & Strauch, 1991 \\
\hline Cattle manure (anaerobic) & 55 & 1 & Strauch, 1991 \\
\hline Liquid manure (Licorn-system) & 53 & 2 & Strauch, 1991 \\
\hline Pig and cattle manure (anaerobic digestion) & 52 to 54 & 1 & Strauch, 1991 \\
\hline Pig slurry (anaerobic thermophilic treatment) & 55 & 1 & Strauch, 1991 \\
\hline
\end{tabular}

${ }^{a}$ NR: Not Reported

Table 8b. Persistence of A. suum and A. galli in Various Slurries (Source: Katakam et al., 2014b)

\begin{tabular}{|c|c|c|c|}
\hline Matrix $^{a}$ & $\begin{array}{c}\text { Temperature } \\
{ }^{\circ} \mathrm{C}\end{array}$ & $\begin{array}{c}\text { A. suum } \\
\text { T50 (Days) } \\
\text { Mean } \\
\text { (Range) }\end{array}$ & $\begin{array}{c}\text { A. galli } \\
\text { T50 (Days) } \\
\text { Mean } \\
\text { (Range) }\end{array}$ \\
\hline Slurry with urea & 20 & $\begin{array}{c}42.3 \\
(40.0 \text { to } 44.5)\end{array}$ & $\begin{array}{c}14.1 \\
(9.5 \text { to } 18.7)\end{array}$ \\
\hline Slurry with urea & 30 & $\begin{array}{c}21.8 \\
(17.2 \text { to } 26.4)\end{array}$ & $\begin{array}{c}1.22 \\
(0.86 \text { to } 1.56)\end{array}$ \\
\hline Slurry with urea & 40 & $\begin{array}{c}0.83 \\
(0.67 \text { to } 0.99)\end{array}$ & $\begin{array}{c}0.05 \\
(0.03 \text { to } 0.07)\end{array}$ \\
\hline Slurry with urea & 50 & $\begin{array}{c}0.06 \\
(0.05 \text { to } 0.06)\end{array}$ & $\begin{array}{c}0.01 \\
(0.01 \text { to } 0.01)\end{array}$ \\
\hline Slurry without urea & 20 & $\begin{array}{c}242.6 \\
(167.6 \text { to } 317.6)\end{array}$ & $\begin{array}{c}24.8 \\
(16.7 \text { to } 32.9)\end{array}$ \\
\hline Slurry without urea & 30 & $\begin{array}{c}41.6 \\
\text { (29.4 to } 53.8)\end{array}$ & $\begin{array}{c}3.81 \\
\text { (3.61 to } 4.01)\end{array}$ \\
\hline Slurry without urea & 40 & $\mathrm{NR}^{\mathrm{b}}$ & $\begin{array}{c}0.42 \\
(0.32 \text { to } 0.51)\end{array}$ \\
\hline Slurry without urea & 50 & $\begin{array}{c}0.08 \\
(0.07 \text { to } 0.08)\end{array}$ & $\begin{array}{c}0.04 \\
(0.03 \text { to } 0.04)\end{array}$ \\
\hline
\end{tabular}

${ }^{\mathrm{a}}$ Moisture content/ Relative Humidity (\%) was not reported; ${ }^{\mathrm{b}}$ NR: Not Reported 
Table 8c. Persistence of $A$. suum with Varying Relative Humidity in Biosolids at Temperatures between 20-30 ${ }^{\circ} \mathrm{C}$

\begin{tabular}{|c|c|c|c|}
\hline & Moisture Content/ Relative Humidity (\%) & $\begin{array}{c}\text { T99 } \\
\text { (Days) }\end{array}$ & Reference \\
\hline 30 to 80 & & 49 & $\begin{array}{c}\text { de Faria et } \\
\text { al., } 2017\end{array}$ \\
\hline 40 & & $\begin{array}{c}15 \text { to } \\
18\end{array}$ & $\begin{array}{c}\text { Yadav, } \\
2003\end{array}$ \\
\hline 60 & & $\begin{array}{c}30 \text { to } \\
56\end{array}$ & $\begin{array}{c}\text { Yadav, } \\
2003\end{array}$ \\
\hline 80 & & $210+$ & $\begin{array}{c}\text { Yadav, } \\
2003\end{array}$ \\
\hline 100 & & $210+$ & $\begin{array}{c}\text { Yadav, } \\
2003\end{array}$ \\
\hline
\end{tabular}

\subsection{Reductions in Numbers and Viability of Ova by Sanitation Management}

Research on sanitation facilities across the world had been centred not only on elucidating factors that speed up decomposition and dehydration, but also on how to ensure complete inactivation of Ascaris eggs in different media (Browell and Nelson, 2006; Espinoza et al., 2010). A number of environmental factors found to speed up these processes include temperature, moisture, ventilation, $\mathrm{pH}$, urea and ammonia (Esrey et al., 1998; Pecson et al., 2007). The various investigations assessed not just the efficacy of these factors in the natural environment, but also the effects of artificial variability in their concentrations. In this section, we review the levels of Ascaris eggs inactivation in the different types of latrines and materials.

\subsection{Treatment of Excreta and Wastewater}

\subsubsection{Onsite sanitation}

3.1.1.1 Dry onsite sanitation systems

All waterless sanitation technologies are on-site. They utilize either the decomposition or dehydration process and produce either compost or biochar as end product (Tables 8 and 9). Decomposition composting sanitation is either urine diverting or non-urine diverting while all dehydrating sanitation are urine diverting. This is because dehydration works better when urine is separated from faeces (Wolgast, 1993; Esrey et al., 1998). The ability of these sanitation systems to inactivate Ascaris eggs depends largely on the length of storage and the type of treatment employed to speed up the drying process (Esrey, 1998; Nelson and Darby, 2001).

Table 9. Characteristics of decomposing waterless sanitation devices used in different parts of the world producing compost products (source: Esrey et al., 1998)

\begin{tabular}{|c|c|c|c|c|c|c|}
\hline Origin & Year & Device & Location & Number of Vaults /Chambers & Design & Processing Time (Months) \\
\hline India & $\mathrm{NR}^{\mathrm{a}}$ & $\begin{array}{c}\text { Double } \\
\text { vault } \\
\text { toilet }\end{array}$ & $\begin{array}{l}\text { Above } \\
\text { land }\end{array}$ & 2 & $\mathrm{UD}^{\mathrm{b}}$ & 12 \\
\hline $\begin{array}{l}\text { Kiribati } \\
\text { Is }\end{array}$ & NR & $\begin{array}{c}\text { Movable } \\
\text { bin } \\
\text { Toilet }\end{array}$ & $\begin{array}{l}\text { Above } \\
\text { land }\end{array}$ & 2 & $\mathrm{NUD}^{\mathrm{c}}$ & 12 \\
\hline Mexico & 1970 & $\begin{array}{l}\text { Sirdo } \\
\text { Seco } \\
\text { toilet }\end{array}$ & $\begin{array}{l}\text { Above } \\
\text { land }\end{array}$ & 2 & NUD & 12 \\
\hline Norway & 1972 & $\begin{array}{l}\text { Carousel } \\
\text { toilet }\end{array}$ & $\begin{array}{l}\text { Below } \\
\text { land }\end{array}$ & 4 to 6 & UD & 12 \\
\hline $\begin{array}{l}\text { South } \\
\text { Pacific }\end{array}$ & 1992 & $\begin{array}{l}\text { CCD } \\
\text { toilet }\end{array}$ & $\begin{array}{l}\text { Above } \\
\text { land }\end{array}$ & 2 & NUD & 12 \\
\hline Swede & 1960 & $\begin{array}{l}\text { Clivus } \\
\text { Multrum } \\
\text { toilet }\end{array}$ & $\begin{array}{l}\text { Above } \\
\text { land }\end{array}$ & 1 & NUD & 12 \\
\hline
\end{tabular}

${ }^{\mathrm{a}} \mathrm{NR}$ : Rot Reported; ${ }^{\mathrm{b}} \mathrm{UD}$ : Urine diverting latrine; ${ }^{\mathrm{c}} \mathrm{NUD}$ : Non urine diverting latrine 


\subsection{Inactivation by storage}

Faecal sludge can be stored in several ways which can broadly be divided into what may be termed "active sludge storage (ASS)" and "inactive sludge storage (ISS)" systems. ASS concerns faecal heap that is still receiving fresh faeces while ISS refers to heaps no longer receiving fresh faeces (Montangero and Strauss, 2002; Strande et al., 2014; Niwagaba et al., 2014). Thus, ISS are sludge heaps that have been removed from either one of twin vaults in double vault toilets or dug up from single vault drop and store toilets or scooped from drop and transfer systems and stored (Dodane et al., 2011). The storage may be above ground and using different types of containers or underground pits (Pompeo et al., 2016). Irrespective of the manner of storage, the objective is always to allow composts to properly form and achieve pathogen die-off before it is used for agricultural purposes.

Studies have shown that Ascaris eggs remain viable in sludge and the environment longer than most other pathogens, and take longer to inactivate (Kaneshiro and Stern, 1986; Jensen et al., 2009). According to Pecson et al. (2007) and Wharton (1980) the persistence of Ascaris eggs in the environment can be explained by the characteristics of its shell which is highly impermeable and has been deemed "one of the most resistant biological structures". For this reason, Ascaris egg has been said to be hardy and a standard for assessing any environmental treatment that is not a pre-approved EPA pathogen reduction technique (US EPA, 1999). An EPA approved technique must be able to inactivate Ascaris eggs below public health importance. Based on this, the various waterless sanitation technologies must prove that their storage design specifications and functional capacities are able to inactivate Ascaris eggs. The period required to achieve this goal vary substantially around the world and significantly depends on prevailing ambient temperature of an area. It is shorter in tropical zones than temperate areas (Kim et al., 2012). For instance, 2-3 years are required in the temperate environment but only 3-12 months in the tropical climate (Tables 9 and 10).

Table 10. Characteristics of dehydrating above land waterless sanitation devices used in different parts of the world (Source: Esrey et al., 1998)

\begin{tabular}{|c|c|c|c|c|c|c|c|c|}
\hline Area & $\begin{array}{l}\text { Years of } \\
\text { Study }\end{array}$ & Device & $\begin{array}{l}\text { Number of } \\
\text { Vaults }\end{array}$ & Design & $\begin{array}{c}\text { Processing Time } \\
\text { (Months) }\end{array}$ & Product & $\begin{array}{l}\text { Absorbent } \\
\text { /Energy }\end{array}$ & $\begin{array}{c}\text { Anal Cleaning } \\
\text { Dropped }\end{array}$ \\
\hline Ecuador & 1985 & $\begin{array}{l}\text { Double } \\
\text { vault }\end{array}$ & 2 & $\mathrm{NUD}^{\mathrm{a}}$ & $\mathrm{NR}^{\mathrm{b}}$ & $\begin{array}{l}\text { Biochar/ } \\
\text { Compost }\end{array}$ & $\begin{array}{c}\text { Solar } \\
\text { heater, } \\
\text { ash, } \\
\text { sawdust }\end{array}$ & NR \\
\hline $\begin{array}{l}\text { El } \\
\text { Salvador }\end{array}$ & 1994 & Tecpan & 1 & $\mathrm{UD}^{\mathrm{c}}$ & 3 & $\begin{array}{l}\text { Biochar/ } \\
\text { Compost }\end{array}$ & $\begin{array}{c}\text { Solar } \\
\text { heater, } \\
\text { ash, } \\
\text { soil/lime }\end{array}$ & No \\
\hline Guatemala & 1978 & Lasf $^{\mathrm{d}}$ & 2 & UD & 12 & Compost & $\begin{array}{l}\text { Ash, soil, } \\
\text { sawdust, } \\
\text { lime }\end{array}$ & No \\
\hline India & NR & $\begin{array}{l}\text { Ladakh } \\
\text { toilet }\end{array}$ & $\mathrm{NA}^{\mathrm{e}}$ & NUD & NR & Compost & Soil, ash & No \\
\hline Sweden & 1980 & $\begin{array}{c}\text { WM } \\
\text { Ekologen }\end{array}$ & NR & UD & 6 & Compost & $\begin{array}{l}\text { Ventpipe, } \\
\text { fan }\end{array}$ & Yes \\
\hline Vietnam & NR & $\begin{array}{l}\text { Double } \\
\text { vault }\end{array}$ & 2 & UD & 2 & Compost & Ash, soil & No \\
\hline Yemen & NR & $\begin{array}{l}\text { Long } \\
\text { drop }\end{array}$ & NR & UD & NR & Biochar & Sunlight & No \\
\hline
\end{tabular}

${ }^{\mathrm{a}}$ NUD: Non urine diverting latrine; ${ }^{\mathrm{b}} \mathrm{NR}$ : Not reported; ${ }^{\mathrm{c} U D}$ : Urine diverting latrine; ${ }^{\mathrm{d}}$ Lasf: Letrina Abonera Seca Familiar Latrine; ${ }^{e}$ NA: Not Applicable; Other factors reported to speed up inactivation include ammonia (Nordin et al., 2009; Katakam et al., 2014a), length of storage (Pompeo et al., 2016), the physico-chemical conditions of the bedding materials (Katakam et al., 2014b) and temperature. 
This means that compost from ASS system from all sanitation facilities must not be used immediately but must be subjected to a reasonable period of inactive storage state before use (Gibson, 2014). The period of inactive storage should normally be longer in temperate than tropical climate zones (Gibson, 2014).

Table 11 presents the direct effect of temperature variability on Ascaris egg inactivation in any given area. Clearly it can be deduced that for every twofold increase in temperature the period required to completely inactivate Ascaris eggs is halved. That is, increasing temperature leads to increasing rate of Ascaris egg inactivation. However, care must be taken in interpreting the mixed data on activation from different sources with different dates and using different analytical procedures. Besides the different methods used to measure the egg inactivation may have different sensitivity and precision, thus raising a risk in cross comparison.

Table 11. Effect of temperature on the time for inactivation of Ascaris eggs

\begin{tabular}{|c|c|c|c|}
\hline Matrices & $\begin{array}{c}\text { Temperature } \\
{ }^{\circ} \mathrm{C} \\
\end{array}$ & $\begin{array}{c}\text { Time for 100\% Inactivation } \\
\text { (Days) }\end{array}$ & Reference \\
\hline $\begin{array}{l}\text { Faecal } \\
\text { sludge }\end{array}$ & $<20$ & 365 to 730 & Carr, 2001 \\
\hline $\begin{array}{l}\text { Faecal } \\
\text { sludge }\end{array}$ & $\geq 20$ & $<365$ & Carr, 2001 \\
\hline $\begin{array}{l}\text { Faecal } \\
\text { sludge }\end{array}$ & $<20$ & Several months & $\begin{array}{l}\text { Schönning and } \\
\text { Stenström, } 2004\end{array}$ \\
\hline $\begin{array}{l}\text { Faecal } \\
\text { sludge }\end{array}$ & 20 to 30 & Several months & $\begin{array}{l}\text { Schönning and } \\
\text { Stenström, } 2004\end{array}$ \\
\hline Faeces & $<20$ & 50 to 200 & $\begin{array}{l}\text { Ambjerg-Nielsen } \\
\text { et al., } 2003\end{array}$ \\
\hline Night soil & 20 to 30 & Many months & $\begin{array}{l}\text { Ambjerg-Nielsen } \\
\text { et al., } 2003\end{array}$ \\
\hline $\begin{array}{l}\text { Sludge } \\
\text { composting }\end{array}$ & Ambient & Many months & $\begin{array}{l}\text { Ambjerg-Nielsen } \\
\text { et al., } 2003\end{array}$ \\
\hline $\begin{array}{l}\text { Sludge } \\
\text { composting }\end{array}$ & 50 to 60 & 7 & $\begin{array}{l}\text { Ambjerg-Nielsen } \\
\text { et al., } 2003\end{array}$ \\
\hline $\begin{array}{l}\text { Waste } \\
\text { stabilization } \\
\text { pond } \\
\text { (retention } \\
\text { time }>20 \\
\text { days) }\end{array}$ & Ambient & 20 & $\begin{array}{l}\text { Ambjerg-Nielsen } \\
\text { et al., } 2003\end{array}$ \\
\hline Soil & $<20$ & 15 to 100 & $\begin{array}{l}\text { Ambjerg-Nielsen } \\
\text { et al., } 2003\end{array}$ \\
\hline Soil & Ambient & Many months & $\begin{array}{c}\text { Esrey et al., } \\
1998\end{array}$ \\
\hline
\end{tabular}




\subsection{Pit latrines, vault toilets, dry toilets}

All waterless drop and store sanitation models can be described as dry toilets (Windberg, 2009). They include the traditional pit (TP) latrine, conventional improved pit (CIP) latrine, slit-trench (ST) latrine, very improved pit (VIP) latrine and vault latrines (Esrey et al., 1998). They however, differ in the type of containment used to store faeces. The pit latrines which range from TP to VIP store faeces in dug out pits, ideally 4-5 meters deep. The pits may or may not be lined with concrete and maybe single or double (Mahenge, 2013). In double pit system, only one is used at a time during which the other is covered. When one is full, the second is opened for use and the full one closed for two or three years before it is evacuated and the compost so formed used as fertilizer (Austin, 2006). Vault toilets use vault boxes of different shapes and sizes (Esrey et al., 1998). Like pit latrines, there are single and double vault models used in the same manner. However, unlike the pit latrine, vault latrines are moveable. Thus, when one vault in a double vault is full, it is removed and stored for 2-3 years before the compost is formed then after that it is used for fertilizer in agricultural farms (Jensen et al., 2009; Vinneral et al., 2009). The composting latrines are basically vault latrines into which desiccants such as ash, sawdust or soil is added. The major processing method in pit and vault latrines is decomposition. According to Uno and SimpsonHebert (2004) pit sludge at any given time decomposes in both the aerobic and anaerobic systems. Aerobic activity takes place near the surface called aerobic zone while anaerobic activity takes place at deeper profile known as anaerobic zone (Niwagaba et al., 2014). Many factors, especially pit and tank design affect the boundary between aerobic and anaerobic zones (Mehl, 2008).
Decomposition kills Ascaris eggs but a substantial number still survives for years. In twin pit and double vault models, storage of one after it is full means that no fresh faeces goes into it and this allows pathogen inactivation and decomposition of the excreted material to continue undisturbed (concept of ISS) (Berendes et al., 2015).

Table 12 summarizes the outcome of several investigations on the level of inactivation and persistence of Ascaris eggs under several conditions. Clearly rate of inactivation is affected by several factors singly or in combination. Working independently, Carr (2001) and Schönnlng and Stenström (2004) showed that rising temperature speeds up rate of inactivation. While Carr (2001) revealed that time taken to achieve a $2 \log _{10}$ reduction in Ascaris eggs in faecal sludge is halved for every $10^{\circ} \mathrm{C}$ rise in temperature, Schönnlng and Stenström (2004) found at least a fourfold reduction at the same level of rise in temperature. Treatment with either quicklime $(\mathrm{CaO})$ or ammonia $\left(\mathrm{NH}_{3}\right)$ had no effect at $20^{\circ} \mathrm{C}$ or less but speeded-up Ascaris egg die-off from temperatures $25^{\circ} \mathrm{C}$ and above. Other additives found to speed up inactivation included $\mathrm{Ca}(\mathrm{OH})_{2}$ and $\left(\mathrm{NH}_{4}\right)_{2} \mathrm{SO}_{4}$. The effectiveness of each of these additives increased with rising temperature. Pecson et al. (2007) investigated the specific effects of varying temperature, $\mathrm{pH}$ and ammonia concentrations on the time it took to inactivate $2 \log _{10}$ (i.e. T99) of Ascaris ova in faecal sludge. Varying $\mathrm{pH}$ from 7 to 12 at $20^{\circ} \mathrm{C}$ reduced by almost one half the time taken (430 to 230 days). Addition of 1000 and $5000 \mathrm{mg} / \mathrm{L}$ of $\mathrm{NH}_{3}$ further reduced the time threefold and fivefold respectively. The same trend was seen with every increase in temperature except that at $50^{\circ} \mathrm{C}$ change in $\mathrm{pH}$ had no further effect and time taken to achieve T99 came down to minutes rather than hours and days.

Table 12. Inactivation of Ascaris eggs in faecal sludge temperature and treatments

\begin{tabular}{|c|c|c|c|c|c|}
\hline Treatment & $\begin{array}{c}\text { Temperature } \\
{ }^{\circ} \mathrm{C} \\
\end{array}$ & pH & $\begin{array}{c}\text { Removal/ Inactivation level } \\
\left(\log _{10}\right)\end{array}$ & $\begin{array}{l}\text { Time }^{\mathrm{a}} \\
\text { (Days) } \\
\end{array}$ & Reference \\
\hline NR & $<20$ & $\mathrm{NR}^{\mathrm{c}}$ & $>2$ & $\begin{array}{l}750 \text { to } \\
1095\end{array}$ & Carr, 2001 \\
\hline NR & 20 to 30 & NR & $>2$ & $<365$ & Carr, 2001 \\
\hline NR & $<20$ & NR & $>2$ & $\begin{array}{c}50 \text { to } \\
200\end{array}$ & $\begin{array}{l}\text { Schönnlng } \\
\text { and } \\
\text { Stenström, } \\
2004\end{array}$ \\
\hline NR & 20 to 30 & NR & $>2$ & $\begin{array}{l}\text { Several } \\
\text { months }\end{array}$ & $\begin{array}{l}\text { Schönnlng } \\
\text { and } \\
\text { Stenström, } \\
2004\end{array}$ \\
\hline $\begin{array}{l}\text { NH3 } \\
(10-50 \%)\end{array}$ & 20 & NR & $<1$ to 2 & $2 h^{b}$ & $\begin{array}{l}\text { Mendez et } \\
\text { al., } 2002\end{array}$ \\
\hline $\begin{array}{l}\mathrm{CaO} \\
(5-40 \%)\end{array}$ & 20 & NR & $<1$ to 2 & $2 \mathrm{~h}$ & $\begin{array}{l}\text { Mendez et } \\
\text { al., } 2002\end{array}$ \\
\hline $\mathrm{Ca}(\mathrm{OH}) 2$ & NR & NR & $<2$ & I & $\begin{array}{l}\text { Gantzer et } \\
\text { al., } 2001\end{array}$ \\
\hline $\mathrm{CaO}$ & NR & NR & $<2$ & 1 & $\begin{array}{c}\text { Gantzer et } \\
\text { al., } 2001\end{array}$ \\
\hline
\end{tabular}




\begin{tabular}{|c|c|c|c|c|c|}
\hline Treatment & $\begin{array}{c}\text { Temperature } \\
{ }^{\circ} \mathrm{C} \\
\end{array}$ & pH & $\begin{array}{c}\text { Removal/ Inactivation level } \\
\left(\log _{10}\right)\end{array}$ & $\begin{array}{l}\text { Time }^{\mathrm{a}} \\
\text { (Days) } \\
\end{array}$ & Reference \\
\hline $\begin{array}{l}\mathrm{NaOH}+1 \% \\
(\mathrm{w} / \mathrm{v}) \\
(\mathrm{NH} 4) 2 \mathrm{SO} 4\end{array}$ & 37 & NR & 2 & 2 & $\begin{array}{l}\text { Kato et al., } \\
2003\end{array}$ \\
\hline $\mathrm{Ca}(\mathrm{OH}) 2$ & 25 & NR & $<2$ & 7 & $\begin{array}{l}\text { Plachy et } \\
\text { al., } 1996\end{array}$ \\
\hline $\begin{array}{l}\mathrm{NaOH}+50 \\
\mathrm{mg} / \mathrm{g} \text { TS of } \\
\text { (NH4)2SO4 }\end{array}$ & Ambient & NR & $<2$ & 10 & $\begin{array}{c}\text { Reimers et } \\
\text { al., 1986a }\end{array}$ \\
\hline $\mathrm{NH} 4 \mathrm{OH}$ & 22 & NR & 2 & 21 & $\begin{array}{c}\text { Ghiglietti } \\
\text { et al., } \\
1997\end{array}$ \\
\hline $\mathrm{CaO}$ & NR & NR & $<2$ & 40 & $\begin{array}{l}\text { Brewster } \\
\text { et al., } \\
2003\end{array}$ \\
\hline $\mathrm{CaO}$ & 45 & NR & 2 & 70 & $\begin{array}{l}\text { Eriksen et } \\
\text { al., } 1996\end{array}$ \\
\hline $\mathrm{Ca}(\mathrm{OH})_{2}$ & Ambient & NR & $<2$ & 98 & $\begin{array}{l}\text { Schuh et } \\
\text { al., } 1984\end{array}$ \\
\hline $\mathrm{NH}_{3} \mathrm{mg} / \mathrm{l}$ & 20 & 7 & 2 & 450 & $\begin{array}{l}\text { Pecson et } \\
\text { al., } 2007\end{array}$ \\
\hline None & 20 & 12 & 2 & 230 & $\begin{array}{l}\text { Pecson et } \\
\text { al., } 2007\end{array}$ \\
\hline 1000 & 20 & 12 & 2 & 87 & $\begin{array}{l}\text { Pecson et } \\
\text { al., } 2007\end{array}$ \\
\hline 5000 & 20 & 12 & 2 & 25 & $\begin{array}{l}\text { Pecson et } \\
\text { al., } 2007\end{array}$ \\
\hline None & 30 & 7 & 2 & 180 & $\begin{array}{l}\text { Pecson et } \\
\text { al., } 2007\end{array}$ \\
\hline None & 30 & 12 & 2 & 24 & $\begin{array}{l}\text { Pecson et } \\
\text { al., } 2007\end{array}$ \\
\hline 1000 & 30 & 12 & 2 & 16 & $\begin{array}{l}\text { Pecson et } \\
\text { al., } 2007\end{array}$ \\
\hline 5000 & 30 & 12 & 2 & 4.8 & $\begin{array}{l}\text { Pecson et } \\
\text { al., } 2007\end{array}$ \\
\hline None & 40 & 7 & 2 & 14 & $\begin{array}{l}\text { Pecson et } \\
\text { al., } 2007\end{array}$ \\
\hline None & 40 & 12 & 2 & 3.4 & $\begin{array}{l}\text { Pecson et } \\
\text { al., } 2007\end{array}$ \\
\hline 5000 & 40 & 12 & 2 & $9.4 \mathrm{~h}$ & $\begin{array}{l}\text { Pecson et } \\
\text { al., } 2007\end{array}$ \\
\hline None & 50 & 7 & 2 & $\begin{array}{l}110 \\
\min ^{\mathrm{d}}\end{array}$ & $\begin{array}{l}\text { Pecson et } \\
\text { al., } 2007\end{array}$ \\
\hline None & 50 & 12 & 2 & $\begin{array}{l}120 \\
\min \end{array}$ & $\begin{array}{l}\text { Pecson et } \\
\text { al., } 2007\end{array}$ \\
\hline 5000 & 50 & 12 & 2 & $97 \mathrm{~min}$ & $\begin{array}{l}\text { Pecson et } \\
\text { al., } 2007\end{array}$ \\
\hline
\end{tabular}

${ }^{a}$ Time in days unless indicated otherwise; ${ }^{b}$ : hours; ${ }^{c}$ NR: Not Reported; ${ }^{d}$ min: minutes 


\subsection{Composting}

The final product of all drop and store latrines is the compost which can be used to fertilize agricultural crops (Table 13). Composts are assessed on the basis of their quality and safety. Quality is the ability of composts to condition soils for better agricultural production, while safety is assessed by the presence and number of pathogens especially Ascaris ova (Magri et al., 2013; Gibson, 2014). Thus, good quality compost must not only be a good soil conditioner for better agricultural production, it must also not contain pathogens that constitute risks to human health.

According to Carr (2001) several factors determine the quality and safety of compost produced by a latrine. Among these factors are the ability to support biological decomposition of sludge, high oxygen tension that is sufficient and able to penetrate the compost heap to maintain aerobic conditions, moisture content of $50-60 \%$, carbon:nitrogen ratio (the $\mathrm{C}: \mathrm{N}$ ratio) in the range of $15: 1$ to $30: 1$ and temperature of $20^{\circ} \mathrm{C}$ and above. In addition, the compost must provide necessary conditions for complete pathogen die-off. Naturally, a variety of organisms contribute to the breakdown of the material in a composting pit. They range in size from viruses, bacteria, fungi and algae to earthworms and insect larvae. All of these play a major role in mixing, aerating, tearing apart and breaking down the contents of the pile in the toilet's processing vault (Gibson, 2014). As long asthey remain inside the vault their activities are good and should be encouraged. It might even be a good idea to place earthworms in the toilet (Nakagin et al., 2016). If the environment is favourable for them they will multiply, burrowing holes through the compost heap, eating odorous organic matter and thereby converting same to rich organic soil.

Table 13. Inactivation of Ascaris eggs in compost of varying ages, pH, moisture content and desiccant treatments

\begin{tabular}{|c|c|c|c|c|c|c|}
\hline Area & Matrix $^{a}$ & pH & Desiccant & $\begin{array}{l}\text { Removal/inactivation Mean } \\
\left(\log _{10}\right)\end{array}$ & $\begin{array}{l}\text { Time } \\
\text { (Days) } \\
\end{array}$ & Reference \\
\hline China & $\begin{array}{l}\text { Compost } \\
\text { (from } \\
\text { UDDT }^{b} \text { ) }\end{array}$ & $\begin{array}{c}9 \text { to } \\
10\end{array}$ & $\mathrm{NR}^{\mathrm{c}}$ & 2 & 120 & $\begin{array}{l}\text { Wang, } \\
1999\end{array}$ \\
\hline China & $\begin{array}{c}\text { Compost } \\
\text { (from } \\
\text { UDDT) }\end{array}$ & $>8$ & NR & .2 & 120 & $\begin{array}{l}\text { Lan et al., } \\
2001\end{array}$ \\
\hline $\begin{array}{l}\text { El } \\
\text { Salvador }\end{array}$ & $\begin{array}{c}\text { Compost } \\
\text { (from } \\
118 \\
\text { UDDT; } \\
38 \text { single } \\
\text { vault) }\end{array}$ & $<11$ & $\begin{array}{l}\text { Ash, lime } \\
\text { or } \\
\text { lime+soil }\end{array}$ & 2 & 700 & $\begin{array}{l}\text { Wang, } \\
1999\end{array}$ \\
\hline $\begin{array}{l}\text { El } \\
\text { Salvador }\end{array}$ & $\begin{array}{c}\text { Compost } \\
\text { (from } \\
118 \\
\text { UDDT; } \\
38 \text { single } \\
\text { vault) }\end{array}$ & $>11$ & $\begin{array}{l}\text { Ash, lime } \\
\text { or } \\
\text { lime+soil }\end{array}$ & 2 & 450 & $\begin{array}{l}\text { Wang, } \\
1999\end{array}$ \\
\hline Vietnam & $\begin{array}{c}\text { Compost } \\
\text { (from 12 } \\
\text { UDDT) } \\
\text { Moisture } \\
24 \text { to } \\
55 \%\end{array}$ & $\begin{array}{c}8.5 \\
\text { to } \\
10.3\end{array}$ & Ash & 1.3 to $>2$ & 63 & $\begin{array}{c}\text { Carlander } \\
\text { and } \\
\text { Westrell } \\
1998\end{array}$ \\
\hline
\end{tabular}

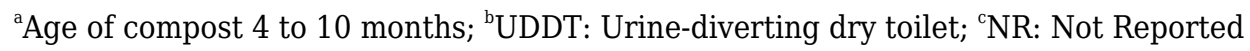

In contrast, helminth parasites, especially the faeces and urine borne, e.g. Ascaris contribute nothing to the process of composting but are important constituent of human excreta discharged into the latrines (Niwagaba et al., 2014). The safety of composts is thus defined by the degree of die-off among these and other pathogenic 
organisms before a compost is used. Usually, as already stated, dynamic activities in the latrines can achieve complete pathogen die-off in compost within 365 to 730 days depending on prevailing conditions. However, the period taken to achieve complete pathogen die-off can be speeded up by artificial treatment of compost. Some of these treatments as discussed in the preceding sections and shown in Table 13 speed up pathogen die-off and achieve complete or near complete (e.g. T99) Ascaris egg inactivation faster than natural processes.

These include increasing temperature, exposure to sunlight and increasing the $\mathrm{pH}$, on the one hand, and decreasing moisture content, nutrient concentration and microorganism density on the other hand. Studies suggest that optimum $\mathrm{pH}$ lies above 11. For instance, at $\mathrm{pH}<11$ (and all other factors kept constant) Wang (1999) achieved complete Ascaris inactivation in 700 days. At pH $>11$ however, and under similar conditions, same level of inactivation was achieved in 450 days, which was 250 days faster.

\subsubsection{Water-based onsite sanitation (septic tanks)}

The septic tank is the receptor and storage device component of the water closet sanitation system. Though an onsite sanitation system, it is split into indoor and outdoor components. The indoor component comprises the water cistern (for water storage) and the bowl (for defaecation). The two components are connected via a pipe network. The septic tank is watertight and receives faeces and flush water (blackwater) from toilets and household sulllage (grey water) from the kitchen (Carr, 2001). Although the faecal sludge in septic tanks can be stored for several years depending on the quantity of faeces per unit time and size of septic tank, it is periodically removed and treated off-site. The offsite treatment is associated with the risk of viable helminth eggs contaminating the environment. The most important of such helminths is the Ascaris which as has been noted earlier is highly resilient (Jensen et al., 2009; Muller et al., 1989). While only a limited report is available in the literature, the few that can be assessed showed that more than half of Ascaris eggs in septage of septic tanks can remain viable for over two years (Table 14). Number of eggs in septage may range from 25 to over 4000 depending on the health status and number of users (Gallizzi, 2003; SANDEC/EAWAG-IWMI, 2003; Jimenez-Cisneros and Maya-Rendon, 2007).

Table 14. Number and viability of Ascaris eggs in fresh sludge, septage and biosolids

\begin{tabular}{|c|c|c|c|c|}
\hline Matrix & Age & Number of Eggs/g & Egg Viability (\%) & Reference \\
\hline $\begin{array}{l}\text { Fresh } \\
\text { sludge } \\
\text { (Ghana) }\end{array}$ & Fresh & 35 to $2.32 \mathrm{E}+02$ & $\mathrm{NR}^{\mathrm{a}}$ & $\begin{array}{l}\text { Jimenez- Cismeros and } \\
\text { Maya-Rendon, } 2007\end{array}$ \\
\hline $\begin{array}{l}\text { Septage } \\
\text { (Country } \\
\text { not } \\
\text { reported) }\end{array}$ & $\begin{array}{l}>2 \\
\text { yrs } \\
\text { old }\end{array}$ & $5.80 \mathrm{E}+02$ & 45 to 82 & $\begin{array}{l}\text { Jimenez- Cismeros and } \\
\text { Maya-Rendon, } 2007\end{array}$ \\
\hline $\begin{array}{l}\text { Septage } \\
\text { (Ghana) }\end{array}$ & NR & $\begin{array}{c}9.00 \mathrm{E}+02 \text { to } \\
6.9 \mathrm{E}+03(\mathrm{n}=7)\end{array}$ & NR & $\begin{array}{c}\text { Gallizzi, 2003; } \\
\text { SANDEC/EAWAG-IWMI, } \\
2003\end{array}$ \\
\hline $\begin{array}{l}\text { Biosolids } \\
\text { (Ghana) }\end{array}$ & NR & 20 to $85(n=8)$ & 45 to 82 & $\begin{array}{c}\text { Gallizzi, 2003; } \\
\text { SANDEC/EAWAG-IWMI, } \\
2003\end{array}$ \\
\hline $\begin{array}{l}\text { Septage } \\
\text { (Country } \\
\text { no } \\
\text { reported) }\end{array}$ & NR & $\pm 4.0 \mathrm{E}+03$ & NR & $\begin{array}{l}\text { Strauss, 1994; Mara } \\
\text { and Cairu, 1989; } \\
\text { Montangero and } \\
\text { Strauss, } 2002\end{array}$ \\
\hline
\end{tabular}

${ }^{\mathrm{a} N R}$ : Not Reported

3.1.3 Wastewater lagoons and stabilization ponds
Table 15 presents the effects of the processes and varying treatment options on the inactivation of Ascaris eggs in wastewater ponds. 
Table 15. Inactivation of Ascaris eggs in sewage of different treatment processes in waste stabilization pond

\begin{tabular}{|c|c|c|c|}
\hline Pond Type $^{a}$ & Treatment & $\begin{array}{c}\text { Removal/Inactivation } \\
\text { Level }\left(\log _{10}\right)\end{array}$ & Reference \\
\hline $\begin{array}{c}\text { Waste } \\
\text { stabilization } \\
\text { pond }^{\text {a }}\end{array}$ & UV & 1 & $\begin{array}{l}\text { Fuhrmann } \\
\text { and } \\
\text { Rudolph, } \\
2009\end{array}$ \\
\hline Waste stabilization pond ${ }^{a}$ & Biological & 0.66 to $>2$ & $\begin{array}{l}\text { Okojokwu and Inabo, 2012; } \\
\text { Awuah, } 2006\end{array}$ \\
\hline Waste stabilization pond ${ }^{\mathrm{a}}$ & $\begin{array}{l}\text { Dialysis } \\
\text { chambers }\end{array}$ & 0.3 to 0.4 & Nelson and Darby, 2002 \\
\hline Waste stabilization pond ${ }^{\mathrm{a}}$ & Sludge cores & 0.3 to 0.4 & Nelson and Darby, 2002 \\
\hline Waste stabilization pond ${ }^{\mathrm{a}}$ & $\begin{array}{l}\text { Biological (14 } \\
\text { days) }\end{array}$ & $0.83 \pm 0.4$ & Shanthala et al., 2007 \\
\hline Waste stabilization pond ${ }^{\mathrm{a}}$ & Biological & 1.3 & Shanthala et al., 2007 \\
\hline Facultative lagoon & Biological & 2.4 & Quiroga, 2011 Reinoso et \\
\hline Facultative lagoon & Biological & 1.12 & al., 2008 \\
\hline Facultative lagoon & Biological & 0.82 to 1.3 & $\begin{array}{l}\text { Hays, 1977; Jimenez- } \\
\text { Cismeros and Maya- } \\
\text { Rendon, } 2007\end{array}$ \\
\hline Facultative lagoon & $\begin{array}{l}\text { Biological } \\
\text { (12 days) }\end{array}$ & $>2$ & $\begin{array}{l}\text { Heinss et al., 1998; } \\
\text { Montangero and Strauss, } \\
2002\end{array}$ \\
\hline
\end{tabular}

${ }^{a}$ Number of ova per litre of water in developing regions 70 to 3000 and in developed regions 1 to 80 (Jimenez-Cismeros and Maya-Rendon, 2007) 
3.1.4 Wastewater treatment and resource recovery facilities

Both the traditional and emerging treatment options aim at removing substantial portions of contaminants and pollutants in wastewater to produce waste stream or solid waste suitable for discharge or reuse. The methods of wastewater treatment are several but can broadly be classified into physical, chemical or biological. They function by mechanical removal of solids, aerobic and anaerobic oxidation, chemical flocculation and sedimentation etc. According to Jimenez-Cisneros and Maya-Rendon (2007) helminth ova including Ascaris ova in wastewater are particles forming a fraction of suspended solids. As a result mechanisms used to remove suspended solids are also used to remove helminth ova from wastewater (Reimers et al., 1986a, Reimers et al., 1986b). These mechanisms according to the authors are sedimentation, filtration and coagulation-flocculation. However, specific investigations to assess the ability of these methods to inactivate Ascaris ova in wastewater are lacking in the literature.

\subsubsection{Biosolids management}

The most important pathogen in biosolids is the Ascaris ova because it persists in the environment longer than other pathogens. Safe use of biosolids to fertilize agricultural farms depends on how much of these pathogens are present and how much made could be inactivated before use. Although theoretically, the process of producing biosolids is on its own capable of killing these pathogens, the process is slow and for Ascaris ova it is even slower (Pecson et al. (2007). This is why contact with inadequately treated biosolids is associated with an increased risk of Ascaris infection (Corrales et al., 2006). This may explain why prevalence of Ascaris infection is usually higher in areas where biosolids is commonly used in agriculture than in areas where they are not.

\subsection{Disinfection}

Sanitisation and disinfection are common words used in wastewater and pathogen management. Both are processes used to reduce microbes and parasites in the environment. Sanitisation technologies were those originally that were known to provide cleanliness and reduction of some level of pathogens mostly bacteria (this was based on experience at the time and not risk or quantitative assessment). Disinfection is based on the use of physical and chemical agents (eg UV and chlorine, ammonia). Sanitizing agents shall be adequate and safe under conditions of use. Any facility, procedure, or machine is acceptable for cleaning and sanitizing equipment and utensils if it is established that the facility, procedure, or machine will routinely render equipment and utensils clean and provide adequate cleaning and sanitizing treatment.
Disinfection uses antimicrobial agents on non-living objects or surfaces to destroy or inactivate microorganisms. Disinfectants may not kill all bacteria, viruses, fungi and spores. Most disinfectants are weakened or inactivated by organic matter such as dirt and feces. Sanitation uses an antimicrobial agent on objects, surfaces or living tissue to reduce the number of disease-causing organisms to nonthreatening levels. Sanitizing does not affect some spores and viruses. A practical method of sanitizing hands is to wash them with soap under running hot water for at least 20 seconds. Sterilization is using chemicals, temperature, gas and/or pressure to kill or inactivate all disease-causing bacteria, spores, fungi and viruses.

\subsubsection{Physical processes for the inactivation of Ascaris}

Table 16 presents the effects of various approaches for the inactivation of Ascaris eggs in different types of faecal matter. The table suggests that many processes have the ability to achieve greater than two or more $\log _{10}$ reduction in Ascaris ova at varying periods of time. Anaerobic digestion under thermophilic condition which appeared to be the most effective technique achieved a $100 \%$ reduction within 4 hours. Composting achieved a similar result but at different periods of time depending on the location of Ascaris eggs in the compost heap. While eggs at the front and back of compost heap were totally inactivated in two days, those at the centre were inactivated half a day faster. The other processes such as exposure to low pressure UV and heat treatment took longer, sometimes up to 14 days (Ligocka and Paluszak, 2009). 
Table 16. Effects of sanitisation processes on the inactivation of Ascaris ova in different types of faecal materials

\begin{tabular}{|c|c|c|c|c|c|}
\hline Matrix & Primary Process & $\begin{array}{c}\text { Medium/Exposure } \\
\text { Pattern }\end{array}$ & Exposure Duration (Days) & $\begin{aligned} & \text { Days to Achieve } \\
&> 2 \log _{10} \text { Reductions } \\
&\end{aligned}$ & Reference \\
\hline $\begin{array}{l}\text { Organic } \\
\text { waste }\end{array}$ & Composting & Front of heap & $\mathrm{NR}^{\mathrm{a}}$ & 2 & $\begin{array}{l}\text { Ligocka } \\
\text { and } \\
\text { Paluszak, } \\
2009\end{array}$ \\
\hline $\begin{array}{l}\text { Organic } \\
\text { waste }\end{array}$ & Composting & $\begin{array}{c}\text { Middle or centre of } \\
\text { heap }\end{array}$ & NR & 1.5 & $\begin{array}{l}\text { Ligocka } \\
\text { and } \\
\text { Paluszak, } \\
2009\end{array}$ \\
\hline $\begin{array}{l}\text { Organic } \\
\text { waste }\end{array}$ & Composting & Back of heap & NR & 2 & $\begin{array}{l}\text { Ligocka } \\
\text { and } \\
\text { Paluszak, } \\
2009\end{array}$ \\
\hline $\begin{array}{l}\text { Organic } \\
\text { waste }\end{array}$ & Fermentation & Mesophilic & NR & 14 & $\begin{array}{l}\text { Ligocka } \\
\text { and } \\
\text { Paluszak, } \\
2009\end{array}$ \\
\hline $\begin{array}{l}\text { Organic } \\
\text { waste }\end{array}$ & Fermentation & Thermophilic & NR & 1 & $\begin{array}{l}\text { Ligocka } \\
\text { and } \\
\text { Paluszak, } \\
2009\end{array}$ \\
\hline Slurry & $\begin{array}{c}\text { Anaerobic } \\
\text { digestion }\end{array}$ & $\begin{array}{l}\text { Thermophilic } \\
\text { bioreactor (Exp } 1 \& \\
\text { 2) }\end{array}$ & NR & $4 \mathrm{~h}$ & $\begin{array}{l}\text { Paluszak } \\
\text { et al., } \\
2016\end{array}$ \\
\hline Slurry & $\begin{array}{l}\text { Low pressure } \\
\text { radiation }\end{array}$ & UV Jm2 & $250^{\mathrm{b}}$ & $10^{\mathrm{b}}$ & $\begin{array}{l}\text { Raynal et } \\
\text { al., } 2012\end{array}$ \\
\hline Slurry & $\begin{array}{l}\text { Low pressure } \\
\text { radiation }\end{array}$ & UV Jm2 & 500 to 750 & 10 & $\begin{array}{l}\text { Raynal et } \\
\text { al., } 2012\end{array}$ \\
\hline Slurry & $\begin{array}{l}\text { Low pressure } \\
\text { radiation }\end{array}$ & UV Jm2 & $1000^{c}$ & $10^{\mathrm{c}}$ & $\begin{array}{l}\text { Raynal et } \\
\text { al., } 2012\end{array}$ \\
\hline Slurry & $\begin{array}{l}\text { Low pressure } \\
\text { radiation }\end{array}$ & UV Jm2 & $10000^{\mathrm{b}}$ & $10^{\mathrm{b}}$ & $\begin{array}{l}\text { Raynal et } \\
\text { al., } 2012\end{array}$ \\
\hline Slurry & Heat Treatment & $70^{\circ} \mathrm{C}$ & $30 s^{d}$ to $3 \min ^{e}$ & 10 & $\begin{array}{l}\text { Raynal et } \\
\text { al., } 2012\end{array}$ \\
\hline Slurry & Heat Treatment & $48^{\circ} \mathrm{C}$ & 6 to $24 \mathrm{~h}^{\mathrm{f}}$ & 10 & $\begin{array}{l}\text { Raynal et } \\
\text { al., } 2012\end{array}$ \\
\hline Slurry & $\begin{array}{l}\text { Low temperature } \\
\text { and ammonia }\end{array}$ & $\begin{array}{c}42^{\circ} \mathrm{C} ; \mathrm{pH} 9 ; 2,000 \\
\mathrm{mg} / \mathrm{l} \mathrm{NH} \mathrm{NH}_{3}-\mathrm{N}\end{array}$ & 18 to $72 \mathrm{~h}$ & 10 & $\begin{array}{l}\text { Raynal et } \\
\text { al., } 2012\end{array}$ \\
\hline
\end{tabular}

${ }^{\mathrm{a}}$ NR: Not Reported; ${ }^{\mathrm{b}}<2 \log _{10}$ reductions at 10 days; ${ }^{\mathrm{c}}<1 \log _{10}$ reductions at 10 days; ${ }^{\mathrm{d}} \mathrm{s}$ : seconds; ${ }^{\mathrm{e}}$ min: minutes; ${ }^{\mathrm{f}} \mathrm{h}$ : hours 


\subsubsection{Chemical Disinfection}

Disinfectants are applied both for preventive and control purposes. At recommended concentrations they are active against microbes, parasites, insects of different sizes and their respective larval stages. Several are for household use while many others are used to disinfect water, surfaces and materials in industries, institutions and several other environments (Oh et al., 2016). Table 17 presents the effect of some common disinfectants on the embryonation and inactivation of Ascaris ova. In a study carried out in Korea, Oh et al., (2016) reported that after 3 weeks of incubation following exposure to ethanol and methanol there was no larval development of decorticated A. suum eggs at all concentrations and exposure time. Chlorohexidin (5\%) also had almost no effect on embryogenesis of $A$. suum eggs In contrast, $10 \%$ povidone iodine, $3 \%$ cresol, $0.2 \%$ sodium hypochlorite, and $0.02 \%$ sodium hypochlorite inhibited embryonation at 3 weeks of incubation. At 6 weeks of incubation, however, eggs exposed to all disinfectants tested showed embryonation regardless of exposure time, except for $10 \%$ povidone iodine. Thus, only $10 \%$ povidone iodine completely inhibited the embryonation of decorticated $A$. suum eggs at 6 weeks of incubation. In another study in South Africa, Naidoo et al. (2016) investigated the effectiveness of four common disinfectants (sodium hypochlorite with and without detergent, carbolic acid and an unknown compound) to inactivate Ascaris ova on different surfaces and media. According to their report, exposure to $50 \%$ of these disinfectants led to a marked decline in the number of viable eggs. Although sodium hypochlorite proved based disinfectants were more effective than the others but none attained up to $2 \log _{10}$ reduction (Table 17). The researchers also reported that eggs exposed to disinfectants appeared decorticated and the chitinous layer was removed.

Table 17. Ability of different disinfectants to inactivate and inhibit embryonation of Ascaris eggs

\begin{tabular}{|c|c|c|c|c|c|}
\hline \multirow{2}{*}{ Disinfectants } & \multirow{2}{*}{$\begin{array}{c}\text { Dilution } \\
\text { Level } \\
(\%)\end{array}$} & \multirow{2}{*}{$\begin{array}{l}\text { Treatment } \\
\text { Duration } \\
\text { (Min) }\end{array}$} & \multicolumn{2}{|c|}{$\begin{array}{c}\text { Removal / } \\
\text { Inactivation } \\
\text { Level } \\
\left(\log _{10}\right)\end{array}$} & \multirow[t]{2}{*}{ Reference } \\
\hline & & & $\begin{array}{c}3 \\
\text { Weeks }^{c}\end{array}$ & $\begin{array}{c}6 \\
\text { Weeks }^{\mathrm{c}}\end{array}$ & \\
\hline Ethanol & $70^{\mathrm{a}}$ & 0.5 to 60 & 0 & 0 & Oh el al., 2016 \\
\hline Ethanol & $99^{\mathrm{a}}$ & 0.5 to 60 & 0 & 0 & Oh et al., 2016 \\
\hline Methanol & $70^{\mathrm{a}}$ & 0.5 to 60 & 0 & 0 & Oh et al., 2016 \\
\hline Methanol & $99^{\mathrm{a}}$ & 0.5 to 60 & 0 & 0 & Oh et al., 2016 \\
\hline Povidone iodine & $10^{\mathrm{a}}$ & 0.5 to 60 & $>3$ & $>3$ & Oh et al., 2016 \\
\hline Cresol & $3^{\mathrm{a}}$ & 0.5 to 60 & 0 to $>2$ & 0 & Oh et al., 2016 \\
\hline Sodium hypochlorite & $0.02^{\mathrm{a}}$ & 0.5 to 60 & 0 to $>2$ & 0 & Oh et al., 2016 \\
\hline Sodium hypochlorite & $0.2^{\mathrm{a}}$ & 0.5 to 60 & 0 to $>2$ & 0 & Oh et al., 2016 \\
\hline Chlorohedidin & $0.2^{\mathrm{a}}$ & 0.5 to 60 & 0 to $<1$ & 0 & Oh et al., 2016 \\
\hline $\begin{array}{l}\text { Sodium hypochlorite } \\
\text { with detergent }\end{array}$ & $50^{b}$ & 1 to 12 & $<1$ to $>1$ & $>1$ & $\begin{array}{l}\text { Naidoo et } \\
\text { al., } 2016\end{array}$ \\
\hline $\begin{array}{l}\text { Sodium hypochlorite } \\
\text { without detergent }\end{array}$ & $50^{\mathrm{b}}$ & 1 to 12 & $<1$ to $>1$ & $>1$ & $\begin{array}{l}\text { Naidoo et } \\
\text { al., } 2016\end{array}$ \\
\hline Carbolic acid & $50^{b}$ & 1 to 12 & $<1$ & $<1$ & $\begin{array}{l}\text { Naidoo et } \\
\text { al., } 2016\end{array}$ \\
\hline Unknown compound & $50+{ }^{b}$ & 1 to 12 & $<1$ & $<1$ & $\begin{array}{l}\text { Naidoo et } \\
\text { al., } 2016\end{array}$ \\
\hline
\end{tabular}

${ }^{\mathrm{a}}$ Diluent was distilled water; ${ }^{\mathrm{b}}$ Diluent was tap water; ${ }^{\mathrm{c}}$ Periods of assessment 


\subsubsection{Ammonia}

Among all disinfecting chemical compounds identified as having ovicidal effects against Ascaris eggs, ammonia appears to be the best. Apart from its effectiveness when used singly, ammonia also helps to quicken the action of other agents of Ascaris inactivation in faecal materials. Several studies on the effectiveness of ammonia as an agent of Ascaris ova inactivation abound in the literature and some of the most recent are presented in Table 18a-d. Data presented show clearly that the rate of ammonia inactivation of Ascaris eggs increases with increasing $\mathrm{pH}$. For instance, at pH 6.8 and ammonia concentration of 2098 $\mathrm{mg} / \mathrm{L}$, a $2 \log _{10}$ inactivation was achieved in 160 days. By increasing the $\mathrm{pH}$ to 10.4 an ammonia concentration of 2637 achieved the same level of inactivation in just 52.5 days which was threefold faster (McKinley et al., 2012). A similar report by Pecson et al. (2007) showed that at $\mathrm{pH} 7$ and no ammonia a $2 \log _{10}$ inactivation was achieved in 450 days at $20^{\circ} \mathrm{C}$. Increasing the $\mathrm{pH}$ to 12 at the same temperature and zero ammonia, the same level of inactivation was attained in 230 days which was half the time taken at $\mathrm{pH}$ 7. By introducing $1000 \mathrm{mg} / \mathrm{L}$ of ammonia at the same pH 12 and temperature of $20^{\circ} \mathrm{C}$ a $2 \log _{10}$ inactivation was achieved within 87 days. The time was further reduced to mere 25 days by increasing ammonia concentration to $5000 \mathrm{mg} / \mathrm{L}$. By increase the temperature at the same levels of $\mathrm{pH}$ and ammonia, inactivation time was further reduced. For instance, at $50^{\circ} \mathrm{C}, 5000 \mathrm{mg} / \mathrm{L}$ ammonia concentration and $\mathrm{pH} 12$, a $2 \log _{10}$ inactivation was achieved within 7 hours. Thus, ammonia activity was exacerbated by increasing $\mathrm{pH}$ and temperature (Pecson et al., 2007; Nordin et al., 2009; Raynal et al., 2012).

Table 18a. Ammonia inactivation of Ascaris ova in urine and varying $\mathrm{pH}$ and temperature

\begin{tabular}{|c|c|c|c|c|c|}
\hline Matrix & $\begin{array}{c}\text { Temperature } \\
{ }^{\circ} \mathrm{C}\end{array}$ & $\mathbf{p H}$ & Ammonia (mg/L) & $\begin{array}{c}\text { Time (Days) } \\
\text { For } 2 \log _{10} \\
\text { Removal/ Inactivation }\end{array}$ & Reference \\
\hline $\begin{array}{l}\text { Stored } \\
\text { urine + } \\
\text { ash }\end{array}$ & 19.5 & 10.4 & 2637 & 52.5 & $\begin{array}{l}\text { McKinley } \\
\text { et al., } \\
2012\end{array}$ \\
\hline $\begin{array}{l}\text { Fresh } \\
\text { urine }\end{array}$ & 19.5 & 6.8 & 2098 & 159.6 & $\begin{array}{l}\text { McKinley } \\
\text { et al., } \\
2012\end{array}$ \\
\hline $\begin{array}{l}\text { Fresh } \\
\text { urine + } \\
\text { ash }\end{array}$ & 19.5 & 10.4 & 540 & 104.3 & $\begin{array}{l}\text { McKinley } \\
\text { et al., } \\
2012\end{array}$ \\
\hline $\begin{array}{l}\text { Urine } \\
\text { at } 1: 0 \\
\text { dilution }\end{array}$ & 14 & $\begin{array}{l}9.0 \\
\text { to } \\
9.1\end{array}$ & 236 & 240 & $\begin{array}{l}\text { Nordin et } \\
\text { al., } 2009\end{array}$ \\
\hline
\end{tabular}




\begin{tabular}{|c|c|c|c|c|c|}
\hline Matrix & $\begin{array}{c}\text { Temperature } \\
{ }^{\circ} \mathbf{C}\end{array}$ & pH & Ammonia (mg/L) & $\begin{array}{c}\text { Time (Days) } \\
\text { For } 2 \log _{10} \\
\text { Removal/ Inactivation }\end{array}$ & Reference \\
\hline $\begin{array}{l}\text { Urine } \\
\text { at } 1: 0 \\
\text { dilution }\end{array}$ & 24 & $\begin{array}{l}9.0 \\
\text { to } \\
9.1\end{array}$ & 141 & 48 & $\begin{array}{l}\text { Nordin et } \\
\text { al., } 2009\end{array}$ \\
\hline $\begin{array}{l}\text { Urine } \\
\text { at 1:0 } \\
\text { dilution }\end{array}$ & 34 & $\begin{array}{l}9.0 \\
\text { to } \\
9.1\end{array}$ & 141 & 3.4 & $\begin{array}{l}\text { Nordin et } \\
\text { al., } 2009\end{array}$ \\
\hline $\begin{array}{l}\text { Urine } \\
\text { at } 1: 0 \\
\text { dilution }\end{array}$ & $\mathrm{NR}^{\mathrm{a}}$ & $\begin{array}{l}9.0 \\
\text { to } \\
9.1\end{array}$ & 57 & 480 & $\begin{array}{l}\text { Nordin et } \\
\text { al., } 2009\end{array}$ \\
\hline $\begin{array}{l}\text { Urine } \\
\text { at } 1: 1 \\
\text { dilution }\end{array}$ & 14 & 8.9 & 39 & 1060 & $\begin{array}{l}\text { Nordin et } \\
\text { al., } 2009\end{array}$ \\
\hline $\begin{array}{l}\text { Urine } \\
\text { at } 1: 1 \\
\text { dilution }\end{array}$ & 24 & 8.9 & 66 & 56 & $\begin{array}{l}\text { Nordin et } \\
\text { al., } 2009\end{array}$ \\
\hline $\begin{array}{l}\text { Urine } \\
\text { at } 1: 1 \\
\text { dilution }\end{array}$ & 34 & 8.9 & 100 & 6.3 & $\begin{array}{l}\text { Nordin et } \\
\text { al., } 2009\end{array}$ \\
\hline $\begin{array}{l}\text { Urine } \\
\text { at } 1: 1 \\
\text { dilution }\end{array}$ & NR & 8.9 & 16 & 840 & $\begin{array}{l}\text { Nordin et } \\
\text { al., } 2009\end{array}$ \\
\hline $\begin{array}{l}\text { Urine } \\
\text { at } 1: 3 \\
\text { dilution }\end{array}$ & 14 & $\begin{array}{c}8.7 \\
\text { to } \\
9.1\end{array}$ & 20 & NR & $\begin{array}{l}\text { Nordin et } \\
\text { al., } 2009\end{array}$ \\
\hline $\begin{array}{l}\text { Urine } \\
\text { at } 1: 3 \\
\text { dilution }\end{array}$ & 24 & $\begin{array}{c}8.7 \\
\text { to } \\
9.1\end{array}$ & 18 & NR & $\begin{array}{l}\text { Nordin et } \\
\text { al., } 2009\end{array}$ \\
\hline $\begin{array}{l}\text { Urine } \\
\text { at } 1: 3 \\
\text { dilution }\end{array}$ & 34 & $\begin{array}{l}8.7 \\
\text { to } \\
9.1\end{array}$ & 40 & 8.5 & $\begin{array}{l}\text { Nordin et } \\
\text { al., } 2009\end{array}$ \\
\hline $\begin{array}{l}\text { Urine } \\
\text { at } 1: 3 \\
\text { dilution }\end{array}$ & NR & $\begin{array}{l}8.7 \\
\text { to } \\
9.1\end{array}$ & 14 & NR & $\begin{array}{l}\text { Nordin et } \\
\text { al., } 2009\end{array}$ \\
\hline Sludge & 44 & $\begin{array}{c}9 \text { to } \\
11\end{array}$ & 200 & $1^{b}$ & $\begin{array}{l}\text { Pecson } \\
\text { and } \\
\text { Nelson, } \\
2005\end{array}$ \\
\hline
\end{tabular}

${ }^{\mathrm{a}}$ NR: Not Reported; ${ }^{\mathrm{b}} \log _{10}$ inactivation $<1 ;{ }^{c} \log _{10}$ inactivation $>2$ 
Table 18b. Inactivation of Ascaris ova in sludge and varying Ammonia, $\mathrm{pH}$ and temperature

\begin{tabular}{|c|c|c|c|c|c|}
\hline Matrix & $\begin{array}{c}\text { Temperature } \\
{ }^{\circ} \mathrm{C} \\
\end{array}$ & pH & Ammonia (mg/L) & $\begin{array}{c}\text { Time (Days) } \\
\text { For } 2 \log _{10} \text { Removal/ Inactivation }\end{array}$ & Reference \\
\hline $\begin{array}{l}\text { Stock } \\
\text { solution }\end{array}$ & 42 & 9 & 2000 & $10^{\mathrm{a}}$ & $\begin{array}{l}\text { Raynal et } \\
\text { al., } 2012\end{array}$ \\
\hline $\begin{array}{l}\text { Sludge } \\
\text { with } \\
\text { urine }\end{array}$ & 24 & 12.5 & 6.6 & 14 & $\begin{array}{l}\text { Ogunyokun } \\
\text { et al., } 2016\end{array}$ \\
\hline $\begin{array}{l}\text { Sludge } \\
\text { with } \\
\text { urea }\end{array}$ & 24 & 8 & 9.1 & 14 & $\begin{array}{l}\text { Ogunyokun } \\
\text { et al., } 2016\end{array}$ \\
\hline Sludge & 20 & 7 & 0 & 450 & $\begin{array}{l}\text { Pecson et } \\
\text { al., } 2007\end{array}$ \\
\hline Sludge & 20 & 12 & 0 & 230 & $\begin{array}{l}\text { Pecson et } \\
\text { al., } 2007\end{array}$ \\
\hline Sludge & 20 & 12 & 1000 & 87 & $\begin{array}{l}\text { Pecson et } \\
\text { al., } 2007\end{array}$ \\
\hline Sludge & 20 & 12 & 5000 & 25 & $\begin{array}{l}\text { Pecson et } \\
\text { al., } 2007\end{array}$ \\
\hline Sludge & 30 & 7 & 0 & 180 & $\begin{array}{l}\text { Pecson et } \\
\text { al., } 2007\end{array}$ \\
\hline Sludge & 30 & 12 & 0 & 24 & $\begin{array}{l}\text { Pecson et } \\
\text { al., } 2007\end{array}$ \\
\hline Sludge & 30 & 12 & 1000 & 16 & $\begin{array}{l}\text { Pecson et } \\
\text { al., } 2007\end{array}$ \\
\hline Sludge & 30 & 12 & 5000 & 0.39 & $\begin{array}{l}\text { Pecson et } \\
\text { al., } 2007\end{array}$ \\
\hline Sludge & 40 & 7 & 0 & 14 & $\begin{array}{l}\text { Pecson et } \\
\text { al., } 2007\end{array}$ \\
\hline Sludge & 40 & 12 & 0 & 3.4 & $\begin{array}{l}\text { Pecson et } \\
\text { al., } 2007\end{array}$ \\
\hline Sludge & 40 & 12 & 5000 & 0.3 & $\begin{array}{l}\text { Pecson et } \\
\text { al., } 2007\end{array}$ \\
\hline Sludge & 50 & 7 & 0 & 100 mins $^{\mathrm{b}}$ & $\begin{array}{l}\text { Pecson et } \\
\text { al., } 2007\end{array}$ \\
\hline Sludge & 50 & 12 & 0 & 120 mins & $\begin{array}{l}\text { Pecson et } \\
\text { al., } 2007\end{array}$ \\
\hline Sludge & 50 & 12 & 5000 & 97 mins & $\begin{array}{l}\text { Pecson et } \\
\text { al., } 2007\end{array}$ \\
\hline $\begin{array}{l}\text { Sludge, } \\
10 \% \text { TS }\end{array}$ & 22 & 9.1 & 2400 & 90 & $\begin{array}{l}\text { Ghigletti, } \\
1997\end{array}$ \\
\hline $\begin{array}{l}\text { Sludge, } \\
10 \% \text { TS }\end{array}$ & 22 & 12 & 9700 & 60 & $\begin{array}{l}\text { Ghigletti, } \\
1997\end{array}$ \\
\hline $\begin{array}{l}\text { Sludge, } \\
10 \% \text { TS }\end{array}$ & 22 & 12.7 & 1200 & 40 & $\begin{array}{l}\text { Ghigletti, } \\
1997\end{array}$ \\
\hline $\begin{array}{l}\text { Sludge, } \\
10 \% \text { TS }\end{array}$ & 22 & 12.7 & 19400 & 21 & $\begin{array}{c}\text { Ghigletti, } \\
1997\end{array}$ \\
\hline \multicolumn{6}{|c|}{${ }^{\mathrm{a}} \log _{10}$ inactivation $>2 ;{ }^{\mathrm{b}}$ Mins: Minutes } \\
\hline
\end{tabular}


Table 18c. Inactivation of Ascaris ova in faeces and varying Ammonia, pH and temperature (Source: Nordin et al., 2009)

\begin{tabular}{|c|c|c|c|c|}
\hline Matrix & $\begin{array}{c}\text { Temperature } \\
{ }^{\circ} \mathrm{C}\end{array}$ & pH & Ammonia (mg/L) & $\begin{array}{c}\text { Time (Days) for } \\
2 \log _{10} \\
\text { Inactivation } \\
\end{array}$ \\
\hline Faeces $+2 \%$ urea & 24 & 9 & 230 & 28 \\
\hline Faeces+1\%urea & 24 & 8.9 & 130 & 47 \\
\hline Faeces+ash+1\%urea & 24 & 12.8 & 220 & 13 \\
\hline Faeces+ash & 24 & 12.8 & 57 & 35 \\
\hline Faeces+urea & 24 & 8.3 & 20 & 74 \\
\hline Faeces+2\%urea & 34 & 9 & 440 & 3.8 \\
\hline Faeces+1\%urea & 34 & 8.9 & 250 & 4.1 \\
\hline Faeces+ash+1\%urea & 34 & 12.8 & 72 & 3.8 \\
\hline Faeces+ash & 34 & 12.8 & 71 & 3.7 \\
\hline Faeces+urea & 34 & 8.3 & 43 & 21 \\
\hline
\end{tabular}

Table 18d. Inactivation of Ascaris ova in water and varying Ammonia, pH and temperature

\begin{tabular}{|c|c|c|c|c|c|}
\hline Matrix & $\begin{array}{c}\text { Temperature } \\
{ }^{\circ} \mathrm{C}\end{array}$ & pH & $\operatorname{Ammonia}(\mathrm{mg} / \mathrm{L})$ & $\begin{array}{c}\text { Time (Days) } \\
\text { For } 2 \log _{10} \\
\text { Inactivation }\end{array}$ & Reference \\
\hline $\begin{array}{l}\text { Deionized } \\
\text { water+ash }\end{array}$ & 19.5 & 10.4 & 47 & 175.7 & $\begin{array}{l}\text { McKinley } \\
\text { et al., } \\
2012\end{array}$ \\
\hline $\begin{array}{l}\text { Water } \\
\text { solution }\end{array}$ & 30 & 11.9 & 2900 & 14 & $\begin{array}{c}\text { Ghigletti, } \\
1997\end{array}$ \\
\hline $\begin{array}{l}\text { Water } \\
\text { solution }\end{array}$ & 40 & 11.9 & 2900 & 7 & $\begin{array}{c}\text { Ghigletti, } \\
1997\end{array}$ \\
\hline $\begin{array}{l}\text { Distilled } \\
\text { water }\end{array}$ & 22 & 12.3 & 2400 & 90 & $\begin{array}{c}\text { Ghigletti, } \\
1997\end{array}$ \\
\hline $\begin{array}{l}\text { Distilled } \\
\text { water }\end{array}$ & 22 & 12.5 & 4800 & 40 & $\begin{array}{c}\text { Ghigletti, } \\
1997\end{array}$ \\
\hline $\begin{array}{l}\text { Distilled } \\
\text { water }\end{array}$ & 22 & 12.7 & $7300+$ & 21 & $\begin{array}{c}\text { Ghigletti, } \\
1997\end{array}$ \\
\hline
\end{tabular}




\section{References}

Adoko, F. (1985). Prevalence of Ascaris lumbricoides in children admitted to the paediatric observation ward, Kenyatta National Hospital, Kenya. MM Degree Thesis, University of Nairobi, Kenya.

Albonico, M., Shamlaye, N., Shamlaye, C. and Savioli, L. (1996). Control of intestinal parasitic infections in Seychelles: a comprehensive and sustainable approach. Bulletin of the World Health Organization. 74, pp. 577-586.

Albonico, M., Smith, P.G., Ercole, E., Hall, A., Chwaya, H.M., Alawi, K.S. et al. (1995). Rate of reinfection with intestinal nematodes after treatment of children with mebendazole or albendazole in a highly endemic area. Transactions of the Royal Society of Tropical Medicine and Hygiene. 89, pp. 538-541.

Amahmid, O., Asmama, S. and Bouhoum, K. (1999). The effect of waste water reuse in irrigation on the contamination level of food crops by Giardia cysts and Ascaris eggs. International Journal of Food Microbiology. 49, pp. 19-26. doi: 10.1016/S0168-1605(99)00058-6.

Ambjerg-Nielsen, K., Hansen, I., Kjalholt, J., Stuer-Lauridesen, F., Hasting, A.B., Stenström, T.A. et al. (2003). Risk assessment of local handling of human faeces with focus on pathogens and pharmaceuticals. Ecosan: Closing the loop. Proceedings of the 2nd International Symposium on Ecological Sanitation incorporating the 1st IWA specialist group conference on sustainable sanitation. pp. 365-373.

Anderson, R.M. and May, R.M. (1991). Infectious Diseases of Humans: Dynamics and Control. Dynamics and Control. OUP Oxford.

Arfaa, F. (1984). Selective Primary Health Care: Strategies for Control of Disease in the Developing World. XII. Ascariasis and Trichuriasis. Reviews of Infectious Diseases. 6, pp. 364-373.

Asaolu, S.O., Holland, C.V. and Crompton, D.W.T. (1991). Community control of Ascaris lumbricoides in rural Oyo State, Nigeria: mass, targeted and selective treatment with levamisole. Parasitology. 103, pp. 291-298. doi: $10.1017 /$ S0031182000059564.

Asaolu, S.O. and Ofoezie, I.E. (2003). The role of health education and sanitation in the control of helminth infections. Acta Tropica. 86, pp. 283-294. doi: 10.1016/S0001-706X(03)00060-3.

Asaolu, S.O., Ofoezie, I.E., Odumuyiwa, P.A., Sowemimo, O.A. and Ogunniyi, T.A.B. (2002). Effect of water supply and sanitation on the prevalence and intensity of Ascaris lumbricoides among pre-school-age children in Ajebandele and Ifewara, Osun State, Nigeria. Transactions of the Royal Society of Tropical Medicine and Hygiene. 96, pp. 600-604. doi: 10.1016/S0035-9203(02)90323-8.

Astral, T. and Rogers, N. (1995). Acute pancreatitis caused by biliary Ascaris in pregnancy. Journal of perinatology. 15(4), pp. 330-332.

Austin, L.M. (2006). Operational safety of urine diversion toilets in Durban, South Africa. Proceedings for the 32nd WEDC International Comference on Sustainable Development of Water Resources, Water Supply and Environmental Sanitation. pp. 1-8.

Awuah, E. (2006). Pathogen removal mechanisms in macrophyte and algal waste stabilization ponds. Wageningen University. Delft, The Netherlands.

Baird, J.K., Mistrey, M., Pimsler, M. and Connor, D.H. (1986). Fatal Human Ascariasis Following Secondary Massive Infection. The American Journal of Tropical Medicine and Hygiene. 35, pp. 314-318. doi: https://doi.org/10.4269/ajtmh.1986.35.314.

Berendes, D., Levy, K., Knee, J., Handzel, T. and Hill, V.R. (2015). Ascaris and Escherichia coli Inactivation in an Ecological Sanitation System in Port-au-Prince, Haiti. PLOS ONE. 10, pp. 1-14. doi: 10.1371/journal.pone.0125336. 
Bethony, J., Brooker, S., Albonico, M., Geiger, S.M., Loukas, A., Diemert, D. et al. (2006). Soil-transmitted helminth infections: ascariasis, trichuriasis, and hookworm. The Lancet. 367, pp. 1521-1532. doi: 10.1016/S0140-6736(06)68653-4.

Blumenthal, D.S. and Schultz, M.G. (1975). Incidence of Intestinal Obstruction in Children Infected with Ascaris Lumbricoides. The American Journal of Tropical Medicine and Hygiene. 24, pp. 801-805. doi: https://doi.org/10.4269/ajtmh.1975.24.801.

Bowman, D.D., Little, M.D. and Reimers, R.S. (2003). Precision and accuracy of an assay for detecting Ascaris eggs in various biosolid matrices. Water Research. 37, pp. 2063-2072. doi: 10.1016/S0043-1354(02)00597-3.

Brewster, J., Oleszkiewicz, J., Bujoczek, G., Reimers, R.S., Abu-Orf, M., Bowman, D. et al. (2003). Inactivation of Ascaris suum eggs in digested and dewatered biosolids with lime and fly ash at bench scale and full scale. Journal of Environmental Health Science and Engineering. 2, pp. 395-400. doi: 10.1139/s03-041.

Brownell, S.A. and Nelson, K.L. (2006). Inactivation of single-celled Ascaris suum eggs by low-pressure UV radiation. Applied and Environmental Microbiology. 72, pp. 2178-2184.

Bundy, D.A.P., Wong, M.S., Lewis, L.L. and Horton, J. (1990). Control of geohelminths by delivery of targeted chemotherapy through schools. Transactions of the Royal Society of Tropical Medicine and Hygiene. 84, pp. 115-120. doi: 10.1016/0035-9203(90)90399-Y.

Carlander, A. and Westrell, T. (1998). A microbiological and sociological evaluation of urine diverting double-vault latrines in Cam Duc, Vietnam. Swedish University of Agricultural Science: Swedish institute for infectious disease control. Masters,

Carr, R. (2001). Excreta-Related Infections and the Role of Sanitation in the Control of Transmission. Water quality guidelines, standards and health, (Fewtrell, L. and Bartram, J., ed.). IWA Publishing. London.

CDC (2015). Ascariasis. DPDx - Laboratory Identification of Parasitic Diseases of Public Health Concern. 2017, Centers for Disease Control and Prevention. Atlanta, GA.

Chukwuma, M.C.C., Ekejindu, I., Agbakoba, N., Ezeagwuna, D.A., Anaghalu, I.C. and Nwosu, D.C. (2009). The Prevalence and Risk Factors of Geohelminth Infections among Primary School Children in Ebenebe Town, Anambra State, Nigeria. Middle East Journal of Scientific Research. 4, pp. 211-215.

Coles, G.C. (1975). Letter: Gastro-intestinal allergy to nematodes. Trans R Soc Trop Med Hyg. 69, pp. $362-363$.

Coles, G.C. (1985). Allergy and immunopathology of ascariasis. Ascariasis and its Public Health Significance. (Crompton, D.W.T., Nesheim, M.C. and Pawlowski, Z.S., ed.). Taylor and Francis. London. pp. 167-184.

Collender, P.A., Kirby, A.E., Addiss, D.G., Freeman, M.C. and Remais, J.V. (2015). Methods for quantification of soiltransmitted helminths in environmental media: current techniques and recent advances. Trends in parasitology. 31, pp. 625-639. doi: 10.1016/j.pt.2015.08.007.

Corrales, L.F., Izurieta, R. and Moe, C.L. (2006). Association between intestinal parasitic infections and type of sanitation system in rural El Salvador. Tropical Medicine and International Health. 11, pp. 1821-1831. doi: 10.1111/j.1365-3156.2006.01737.x.

Croll, N.A., Anderson, R.M., Gyorkos, T.W. and Ghadirian, E. (1982). The population biology and control of Ascaris lumbricoides in a rural community in Iran. Transactions of the Royal Society of Tropical Medicine and Hygiene. 76, pp. 187-197. doi: 10.1016/0035-9203(82)90272-3.

Crompton, D.W.T. and Pawlowski, Z.S. (1989). Biology of Ascariasis. Ascariasis and its Prevention and Control. Taylor and Francis. London. pp. 9-44.

Crompton, D.W.T. and Pawlowski, Z.S. (1985). Life history and development of Ascaris lumbricoides and the persistence of human ascariasis. Ascariasis and its Public Health Significance. (Crompton, D.W.T., Nesheim, M.C. and Pawlowski, Z.S., ed.). Taylor and Francis. London. pp. 9-44. 
Dąbrowska, J., Zdybel, J., Karamon, J., Kochanowski, M., Stojecki, K., Cencek, T. et al. (2014). Assessment of viability of the nematode eggs (Ascaris, Toxocara, Trichuris) in sewage sludge with the use of LIVE/DEAD Bacterial Viability Kit. Annals of Agricultural and Environmental Medicine. 21, pp. 35-41.

Dada, E.O. (2016). Prevalence of human intestinal parasite infection among primary school children in Ipogun, Ifedore L. G. A., Ondo State, Nigeria. Journal of Global Biosciences. 5, pp. 3401-3407.

Dada, E.Oluyemi and Aruwa, C.Eleojo (2015). Prevalence of Human Intestinal Helminth Parasites among Undergraduate Students at the off Campus (North Gate Area), Federal University of Technology, Akure (Futa), Nigeria. OALib. 02, pp. 1-6. doi: 10.4236/oalib.1101399.

da Rocha, M.Carolina V., Barés, M.Eboly and Braga, M.Cristina B. (2016). Quantification of viable helminth eggs in samples of sewage sludge. Water Research. 103, pp. 245-255. doi: 10.1016/j.watres.2016.07.039.

de Faria, M.F., Guerrini, I.A., Oliveira, F.C., Sato, M.Inês Z., Hachich, E.M., Passos, J.Raimundo S. et al. (2017). Persistence of Ascaris spp. Ova in Tropical Soil Cultivated with Eucalyptus and Fertilized with Municipal Biosolids. Journal of Environment Quality. 46, pp. 522-527. doi: 10.2134/jeq2016.08.0305.

de Silva, N.R., Guyatt, H.L. and Bundy, D.A.P. (1997). Morbidity and mortality due to Ascaris-induced intestinal obstruction. Transactions of the Royal Society of Tropical Medicine and Hygiene. 91, pp. 31-36. doi: 10.1016/S0035-9203(97)90384-9.

de Victorica, J. and Galván, M. (2003). Preliminary testing of a rapid coupled methodology for quantitation/viability determination of helminth eggs in raw and treated wastewater. Water Research. 37, pp. 1278-1287. doi: 10.1016/S0043-1354(02)00477-3.

Dold, C. and Holland, C.V. (2011). Ascaris and ascariasis. Microbes and Infection. 13, pp. 632-637. doi: 10.1016/j.micinf.2010.09.012.

Eddy, T.P. (1985). Ascaris in rural England: a reply to Dr. Denham. Transactions of The Royal Society of Tropical Medicine and Hygiene. 79, pp. 732-733. doi: 10.1016/0035-9203(85)90206-8.

Eriksen, L., Andreasen, P. and Ilsøe, B. (1996). Inactivation of Ascaris suum eggs during storage in lime treated sewage sludge. Water Research. 30, pp. 1026-1029. doi: 10.1016/0043-1354(95)00258-8.

Espinoza, L.M.C., Yeh, D., Vinneras, B., Rajaram, L., Whiteford, L., Corvin, J. et al. (2012). Inactivation of Ascaris suum by ammonia in feces simulating the parameters of the solar toilet. Journal of Applied Sciences in Environmental Sanitation.

Esrey, S., Gough, J., Rapaport, D., Sawyer, R., Simpson-Hebert, M., Vargas, J. et al. (1998). Ecological sanitation.

W. Foor, E. (1967). Ultrastructural Aspects of Oocyte Development and Shell Formation in Ascaris lumbricoides. The Journal of Parasitology. 53, pp. 1245-1261. doi: 10.2307/3276689.

Fuhrmann, T. and Rudolph, K.U. (2009). Advanced disinfection of wastewater ponds' effluent by UV irradiation. 8th IWA Specialist Group Conference on Waste Stabilization Ponds. International Water Association. Belo Horizonte, Brazil. pp. 8.

Fung, I.Chun-Hai and Cairncross, S. (2009). Ascariasis and handwashing. Transactions of The Royal Society of Tropical Medicine and Hygiene. 103, pp. 215-222. doi: 10.1016/j.trstmh.2008.08.003.

Gallizzi, K. (2003). Co-Composting Reduces Helminth Eggs in Fecal Sludge.

Galvin, T.J. (1968). Development of Human and Pig Ascaris in the Pig and Rabbit. The Journal of Parasitology. 54, pp. 1085-1091. doi: 10.2307/3276967.

Gantzer, C., Gaspard, P., Galvez, L., Huyard, A., Dumouthier, N. and Schwartzbrod, J. (2001). Monitoring of bacterial and parasitological contamination during various treatment of sludge. Water Research. 35, pp. 3763-3770. doi: 10.1016/S0043-1354(01)00105-1. 
Gaspard, P., Wiart, J. and Schwartzbrod, J. (1996). A Method for Assessing the Viability of Nematode Eggs in Sludge. Environmental Technology. 17, pp. 415-420. doi: 10.1080/09593331708616401.

Gelpi, A.P. and Mustafa, A. (1967). Seasonal Pneumonitis with Eosinophilia. The American Journal of Tropical Medicine and Hygiene. 16, pp. 646-657. doi: https://doi.org/10.4269/ajtmh.1967.16.646.

Ghiglietti, R., Genchi, C., Di Matteo, L., Calcaterra, E. and Colombi, A. (1997). Survival of Ascaris suum eggs in ammoniatreated wastewater sludges. Bioresource Technology. 59, pp. 195-198. doi: 10.1016/S0960-8524(96)00147-2.

Ghiglietti, R., Genchi, C., Di Matteo, L., Calcaterra, E. and Colombi, A. (1997). Survival of Ascaris suum eggs in ammoniatreated wastewater sludges. Bioresource Technology. 59, pp. 195-198. doi: 10.1016/S0960-8524(96)00147-2.

Gibson, D.A. (2014). Inactivation of Ascaris in double-vault urine diverting composting latrines in Panama: Methods and environmental health engineering field applications. University of South Florida. Florida, USA.

Goodman, D., Haji, H.J., Bickle, Q.D., Stoltzfus, R.J., Tielsch, J.M., Ramsan, M. et al. (2007). A comparison of methods for detecting the eggs of Ascaris, Trichuris, and Hookworm in infant stool, and the epidimiology of infection in Zanzibari infants. The American Journal of Tropical Medicine and Hygiene. 76, pp. 725-731. doi: https://doi.org/10.4269/ajtmh.2007.76.725.

Guy, K., Myers, P., Espinosa, R., Parr, C.S., Jones, T., Hammond, G.S. et al. (2017). Ascaris lumbricoides human intestinal roundworm. The Animal Diversity Web .

Hagel, I. and Giusti, T. (2010). Ascaris lumbricoides: An Overview of Therapeutic Targets. Infectious Disorders - Drug Targets. 10, pp. 349-367. doi: 10.2174/187152610793180876.

Hays, B.D. (1977). Potential for parasitic disease transmission with land application of sewage plant effluents and sludges. Water Research. 11, pp. 583-595. doi: 10.1016/0043-1354(77)90170-1.

Heinss, U., Larmie, S.A. and Strauss, M. (1998). Solids separation and pond systems for the treatment of faecal sludges in the tropics. Lessons learnt and recommendations for preliminary design.

Henry, F.J. (1981). Environmental sanitation infection and nutritional status of infants in rural St. Lucia, West Indies. Transactions of the Royal Society of Tropical Medicine and Hygiene. 75, pp. 507-513. doi: 10.1016/0035-9203(81)90187-5.

Hlaing, T., Saw, T. and Lwin, M. (1987). Reinfection of people with Ascaris lumbricoides following single, 6-month and 12month interval mass chemotherapy in Okpo village, rural Burma. Transactions of The Royal Society of Tropical Medicine and Hygiene. 81, pp. 140-146. doi: 10.1016/0035-9203(87)90306-3.

Holland, C.V. and Asaolu, S.O. (1990). Ascariasis in Nigeria. Parasitology Today. 6, pp. 143-147. doi: 10.1016/0169-4758(90)90331-W.

Hotez, P. and Herricks, J. (2015). One million deaths by parasites.

Júnior, D.R. de Andr, Karam, J.A., M. Warth, do.P., de Marca, A.F., Jukemura, J., Machado, M.C. et al. (1992). Massive infestation by Ascaris lumbricoides of the biliary tract: report of a successfully treated case. Revista do Instituto de Medicina Tropical de São Paulo. 34, pp. 71-75.

Jeandron, A., Ensink, J.H.J., Thamsborg, S.M., Dalsgaard, A. and Sengupta, M.E. (2014). A Quantitative Assessment Method for Ascaris Eggs on Hands. PLOS ONE. 9, pp. e96731. doi: 10.1371/journal.pone.0096731.

Jensen, P.K.M., Phuc, P.D., Konradsen, F., Klank, L.T. and Dalsgaard, A. (2009). Survival of Ascaris eggs and hygienic quality of human excreta in Vietnamese composting latrines. Environmental Health. 8, pp. 57-65. doi: 10.1186/1476-069X-8-57.

Jia, T.-.W., Melville, S., Utzinger, J., King, C.H. and Zhou, X.-.N. (2012). Soil-Transmitted Helminth Reinfection after Drug Treatment: A Systematic Review and Meta-Analysis. PLOS Neglected Tropical Diseases. 6, pp. e1621. doi: 10.1371/journal.pntd.0001621. 
Jimenez-Cisneros, B.E. and Mendez-Vilas, A. (2007). Helminths and sanitation. Communicating current research and educational topics and trends in applied microbiology. (Maya-Rendon, C., ed.). FORMATEX. Badajoz. pp. 60-71.

Kaneshiro, E.S. and Stern, G. (1986). Survival of parasite eggs in stored sludge. United States Environmental Protection Agency. pp. 1-6.

Katakam, K.Kumar, Mejer, H., Dalsgaard, A., Kyvsgaard, N.Christian and Thamsborg, S.Milan (2014). Survival of Ascaris suum and Ascaridia galli eggs in liquid manure at different ammonia concentrations and temperatures. Veterinary Parasitology. 204, pp. 249-257. doi: 10.1016/j.vetpar.2014.05.017.

Katakam, K.Kumar, ROEPSTORFF, A.L.L.A.N., POPOVIC, O.L.G.A., KYVSGAARD, N.I.E.L.S.C., Thamsborg, S.Milan and Dalsgaard, A. (2013). Viability of Ascaris suum eggs in stored raw and separated liquid slurry. Parasitology. 140, pp. 378-384. doi: 10.1017/S0031182012001722.

Katakam, K.Kumar, Thamsborg, S.Milan, Kyvsgaard, N.Christian, Dalsgaard, A. and Mejer, H. (2014). Development and survival of Ascaris suum eggs in deep litter of pigs. Parasitology. 141, pp. 1646-1656. doi: 10.1017/S0031182014000912.

Kato, S., Fogarty, E. and Bowman, D. (2003). Effect of aerobic and anaerobic digestion on the viability of Cryptosporidium parvum oocysts and Ascaris suum eggs. International Journal of Environmental Health Research. 13, pp. 169-179. doi: 10.1080/0960312031000098071.

Kightlinger, L.K., J. Seed, R. and Kightlinger, M.Boodhoo (1996). Ascaris lumbricoides Aggregation in Relation to Child Growth Status, Delayed Cutaneous Hypersensitivity, and Plant Anthelmintic Use in Madagascar. The Journal of Parasitology. 82, pp. 25-33. doi: 10.2307/3284110.

Kim, M.K., Pyo, K.-.H., Hwang, Y.-.S., Park, K.Hwan, Hwang, I.Gyun, Chai, J.-.Y. et al. (2012). Effect of Temperature on Embryonation of Ascaris suum Eggs in an Environmental Chamber. The Korean Journal of Parasitology. 50, pp. 239-242. doi: 10.3347/kjp.2012.50.3.239.

Lan, Y., Xueming, L., Qinhua, W., Hongbo, X., Caiyun, N. and Lianghong, N. (2001). Observation of the inactivation effect on eggs of Ascaris ssum in urine diverting toilets. First International Conference on Ecological Sanitation. International Conference on Ecological Sanitation. Nanning, China. pp. 125.

Li, D., Sun, L., Wu, D. and Jand, S. (1991). Treatment of 119 cases with biliary ascariasis with decoction of Artemisia capillariens and Coptis chinensis. Tianjin Journal of Traditional Chinese Medicine. 22, pp. 9-10.

Ligocka, A. and Paluszak, Z. (2009). Effectiveness of different sanitisation technologies on the inactivation of Ascaris suum eggs in organic waste. Bulletin of the Veterinary Institute in Puławy. 53, pp. 641-644.

Lu, S. (1992). Observations on therapeutic effects on treatment of 167 cases with biliary ascariasis with complex decoction of Cotex miliae toosendan. Human Journal of Traditional Medicine. 12, pp. 127.

Magri, M.E., Philippi, L.S. and Vinnerås, B. (2013). Inactivation of Pathogens in Feces by Desiccation and Urea Treatment for Application in Urine-Diverting Dry Toilets. Applied and Environmental Microbiology. 79, pp. 2156-2163. doi: 10.1128/AEM.03920-12.

Mahenge, A.S. (2013). The study on ecological sanitation system in Dar-es-Salam (Tanzania). International Journal of Development and Sustainability. 2, pp. 2256-2265.

Mara, D. and Cairu, C.S. (1989). Guidelines for the safe use of wastewater, and excreta in agriculture and agriculture measures for public health protection. WHO. Geneva. pp. 187.

Maya, C., Jimenez, B. and Schwartzbrod, J. (2006). Comparison of Techniques for the Detection of Helminth Ova in Drinking Water and Wastewater. Water Environment Research. 78, pp. 118-124.

McKinley, J.W., Parzen, R.E. and Guzmán, Á.Mercado (2012). Ammonia Inactivation of Ascaris Ova in Ecological Compost by Using Urine and Ash. Applied and Environmental Microbiology. 78, pp. 5133-5137. doi: 10.1128/AEM.00631-12. 
Mehl, J.A. (Submitted). Pathogen destruction and aerobic decomposition in composting latrines: A study from rural Panama. Michigan Technological University. Michigan, USA.

Mendez, J.M., Jiménez, B.E. and Barrios, J.A. (2002). Improved alkaline stabilization of municipal wastewater sludge. Water Science and Technology. 46, pp. 139.

Montangero, A. and Strauss, M. (2002). Faecal sludge treatment.

Muller, M., Sanchez, R.M. and Suswillo, R.R. (1989). Evaluation of a sanitation programme using eggs of Ascaris lumbricoides in household yard soils as indicators. Tropical Medicine and Hygiene. 92, pp. 10-16.

Naidoo, A., Archer, C., Louton, B. and Rodda, N. (2016). Testing household disinfectants for the inactivation of helminth eggs on surfaces and in spills during pit latrine emptying. Water South Africa. 4, pp. 1-11.

Nakagiri, A., Niwagaba, C.B., Nyenje, P.M., Kulabako, R.N., Tumuhairwe, J.B. and Kansiime, F. (2016). Are pit latrines in urban areas of Sub-Saharan Africa performing? A review of usage, filling, insects and odour nuisances. BMC Public Health. 16, pp. 120. doi: 10.1186/s12889-016-2772-z.

Nelson, K.L. and Darby, J.L. (2002). Determination of the Inactivation Rate of Ascaris Eggs in Wastewater Stabilization Pond Sludge Using Dialysis Chambers and Sludge Cores. Water Environment Research. 74, pp. 362-369.

Nelson, K.L. and Darby, J.L. (2001). Inactivation of Viable Ascaris Eggs by Reagents during Enumeration. Applied and Environmental Microbiology. 67, pp. 5453-5459. doi: 10.1128/AEM.67.12.5453-5459.2001.

Nikolay, B., Brooker, S.J. and Pullan, R.L. (2014). Sensitivity of diagnostic tests for human soil-transmitted helminth infections: a meta-analysis in the absence of a true gold standard. International Journal for Parasitology. 44, pp. 765-774. doi: 10.1016/j.ijpara.2014.05.009.

Niwagaba, C.B., Mbaye, M. and Strande, L. (2014). Faecal sludge quantification, characteristics and treatment objectives. Faecal sludge management: Systems approach for implementation and operations. (Strande, L., Ronteltap, M. and Brdjanovic, D., ed.). IWA Publishing. London. pp. 19-44.

Nordin, A., Nyberg, K. and Vinnerås, B. (2009). Inactivation of Ascaris Eggs in Source-Separated Urine and Feces by Ammonia at Ambient Temperatures. Applied and Environmental Microbiology. 75, pp. 662-667. doi: 10.1128/AEM.01250-08.

Nwoke, E.U., Ibiam, G.A., Odikamnoro, O.O., Umah, O.V., Arom, O.T. and Orji, I. (2013). Examination of soil samples for the incidence of geohelminth parasites in Ebonyi north-central area of Ebonyi State, south-east of Nigeria. Archives of Applied Science Research. 5, pp. 41-48.

Odinaka, K.K., Nwolisa, E.C., Mbanefo, F., Iheakaram, A.C. and Okolo, S. (2015). Prevalence and pattern of soil-transmitted helminthic infection among primary school children in a rural community in Imo State, Nigeria. Journal of Tropical Medicine. 2015, pp. 1-4.

Odu, N.N., Elechi, V.I. and Okonko, I.O. (2013). Prevalence of intestinal helminthes infections among primary school children in urban and semi-urban areas in Rivers State, Nigeria. World Rural Observations. 5, pp. 52-61.

Ogunyoku, T.A., Habebo, F. and Nelson, K.L. (2016). In-toilet disinfection of fresh fecal sludge with ammonia naturally present in excreta. Journal of Water, Sanitation and Hygiene for Development. 6, pp. 104. doi: 10.2166/washdev.2015.233.

Oh, K.S., Kim, G.T., Ahn, K.S. and Shin, S.S. (2016). Effects of Disinfectants on Larval Development of Ascaris suum Eggs. The Korean Journal of Parasitology. 54, pp. 103-107. doi: 10.3347/kjp.2016.54.1.103.

Okonjokwu, O.J. and Inabo, H.I. (2012). Comparative parasitological evaluation of wastewater using biosand filters and waste stabilisation ponds. World Journal of Life Sciences and Medical Research. 2, pp. 8-15.

Paluszak, Z., Skowron, K., Bauza-Kaszewska, J., Olszewska, H. and Kroplewska, M. (2016). Sanitary validation of the process of anaerobic digestion of slurry based on the survival of Salmonella Senftenberg (W775, H2S Negative) and 
Ascaris suum eggs. Acta Scientiarum Polonorum seria Agricultura. 15, pp. 49-59.

Pawlowski, Z.S. and Arfaa, R. (1985). Chapter 41, Ascariasis. Tropical and Geographical Medicine. (Warren, K.S. and Mahmoud, A.A.F., ed.). McGraw Hill. New York. pp. 347-358.

Pecson, B.M., Barrios, J.Antonio, Jiménez, B.Elena and Nelson, K.L. (2007). The effects of temperature, pH, and ammonia concentration on the inactivation of Ascaris eggs in sewage sludge. Water Research. 41, pp. 2893-2902. doi: 10.1016/j.watres.2007.03.040.

Pecson, B.M., Barrios, J.Antonio, Johnson, D.R. and Nelson, K.L. (2006). A Real-Time PCR Method for Quantifying Viable Ascaris Eggs Using the First Internally Transcribed Spacer Region of Ribosomal DNA. Applied and Environmental Microbiology. 72, pp. 7864-7872. doi: 10.1128/AEM.01983-06.

Pecson, B.M. and Nelson, K.L. (2005). Inactivation of Ascaris suum Eggs by Ammonia. Environmental Science and Technology. 39, pp. 7909-7914. doi: 10.1021/es050659a.

Periago, M.V., Diniz, R.C., Pinto, S.A., Yakovleva, A., Correa-Oliveira, R., Diemert, D.J. et al. (2015). The Right Tool for the Job: Detection of Soil-Transmitted Helminths in Areas Co-endemic for Other Helminths. PLOS Neglected Tropical Diseases. 9, pp. 1-15. doi: 10.1371/journal.pntd.0003967.

Perry, R.N. and Clarke, A.J. (1981). Hatching mechanisms of nematodes. Parasitology. 83, pp. 435-449. doi: 10.1017/S0031182000085413.

Plachý, P., Juris, P., Plachá, I. and Venglovsky, J. (1996). Use of hydrated lime for disinfection of sewage sludge containing Salmonella typhimurium and Ascaris suum as model pathogens. Veterinární medicína. 41, pp. 255-259.

Pompeo, R.P., Andreoli, C.V., de Castro, E.A. and Aisse, M.M. (2016). Influence of Long-Term Storage Operating Conditions on the Reduction of Viable Ascaris Eggs in Sewage Sludge for Agricultural Reuse. Water, Air, and Soil Pollution. 227, pp. 144. doi: 10.1007/s11270-016-2816-0.

Pullan, R.L., Smith, J.L., Jasrasaria, R. and Brooker, S.J. (2014). Global numbers of infection and disease burden of soil transmitted helminth infections in 2010. Parasites and Vectors. 7, pp. 1-37. doi: 10.1186/1756-3305-7-37.

Quiroga, F.J. (2011). Waste stabilization ponds for waste water treatment, anaerobic pond. The College of Engineering at Iowa State University.

Raynal, M., Villegas, E.N. and Nelson, K.L. (2012). Enumeration of viable and non-viable larvated Ascaris eggs with quantitative PCR. Journal of Water and Health. 10, pp. 594-604. doi: 10.2166/wh.2012.101.

Reimers, R.S., McDonell, D.B., Little, M.D., Bowman, D.D., Englande, A.J. and Henriques, W.D. (1986). Effectiveness of Wastewater Sludge Treatment Processes to Inactivate Parasites. Water Science and Technology. 18, pp. 397-404.

Reimers, R.S., Little, M.D., Englande, A.J., McDonell, D.B., Bowman, D.B., Hughes, J.M. et al. (1981). Parasites in southern sludges and disinfection by standard sludge treatment. USEPA. pp. 82-1023.

Reimers, R.S., Little, M.D., Englande, A.J., McDonell, D.B., Bowman, D.D. and Hughes, J.M. (1986). Investigation of Parasites in Sludges and Disinfection Techniques. US Environmental Protection Agency. Cincinatti, OH. pp. 234.

Reinoso, R., Torres, L.Alexandra and Bécares, E. (2008). Efficiency of natural systems for removal of bacteria and pathogenic parasites from wastewater. Science of The Total Environment. 395, pp. 80-86. doi: 10.1016/j.scitotenv.2008.02.039.

Robertson, L.J., Crompton, D.W.T., Walters, D.E., Nesheim, M.C., Sanjur, D. and Walsh, E.A. (1989). Soil-transmitted helminth infections in school children from Cocle Province, Republic of Panama. Parasitology. 99, pp. 287-292. doi: 10.1017/S0031182000058741.

Rossi, M.A. and Bisson, F.W. (1983). Fatal Case of Multiple Liver Abscesses caused by Adult Ascaris Lumbricoides. The American Journal of Tropical Medicine and Hygiene. 32, pp. 523-525. doi: https://doi.org/10.4269/ajtmh.1983.32.523. 
SANDEC/EAWAN-IWMI (2003). Co-composting of faecal sludge and municipal organ waste: A literature and state-ofknowledge review. IWMI, Accra. pp. 44.

Schönning, C. and Stenström, T.A. (2004). Guidelines on the Safe Use of Urine and Faeces in Ecological Sanitation Systems. Environment Institute. Stockholm. Sweden.

Schuh, R., Philipp, W. and Strauch, D. (1984). Influence of sewage sludge with and without lime treatment on the development of Ascaris suum eggs. (Strauch, D., Havelaar, A.H. and L'Hermite, P., ed.). Elsevier Applied Science Publishers. London. pp. 100-110.

Shanthala, M., Hosetti, B.B. and Stott, R. (2007). Removal of helminth parasitic eggs from waste wtabilization ponds at Shimoga. The BioScan. 2, pp. 9-14.

Shehu, M.M., Kabiru, A., Abubakar, U. and Mohammed, K. (2013). Prevalence of intestinal helminths infections among school children in relation to occupation of parents and toilet facilities in Maru L. G. A., Zamfara. Journal of Biology, Agriculture and Healthcare. 3, pp. 87-90.

Shoff, W.H. (2015). Pediatric Ascariasis. 2017, Medscape.

Simonart, T., Roussel, S. and Gireaudot-Liepman, M.F. (2003). Desk study on European standard for the enumeration of viable helminth ova in sludge, soil and solid waste. Draft Report on Helminth ova. HORIZONTAL-WP3-5. pp. 13.

Stephenson, L.S., Crompton, D.W.T., Latham, M.C., Arnold, S.E. and Jansen, A.A.J. (1983). Evaluation of a Four Year Project to Control Ascaris Infection in Children in Two Kenyan Villages. Journal of Tropical Pediatrics. 29, pp. 175-184. doi: 10.1093/tropej/29.3.175.

Strande, L., Ronteltap, M. and Brdjanovic, D. (2014). Faecal sludge management: Systems approach for implementation and operations. IWA Publishing. London.

Strauch, D. (1991). Survival of pathogenic micro-organisms and parasites in excreta, manure and sewage sludge. Revue scientifique et technique (International Office of Epizootics). 10, pp. 813-846.

Strauss, M. (1994). Health Implications of Excreta and Wastewater Use. Hubei Environmental Sanitation Study 2nd Workshop, Wuhan, China.

Subahar, R. and Sutanto, L. (2008). Ascaris lumbricoides Eggs and Human-Intestinal Protozoan Cysts found in River Water of Angke River, Jakarta. Makara Journal of Health Research. 12, pp. 83-85.

Taylor, L. (2005). Epazote - Chenopodium ambrosioides for worm expeller in Latin America. The healing power of rainforest herbs. Square One Publishers. Milan County, TX.

Tripathy, K., Duque, E., Bolaños, O., Lotero, H. and Mayoral, L.Guillermo (1972). Malabsorption syndrome in ascariasis. The American Journal of Clinical Nutrition. 25, pp. 1276-1281.

Tripathy, K., González, F., Lotero, H. and Bolaños, O. (1971). Effects of Ascaris Infection on Human Nutrition*. The American Journal of Tropical Medicine and Hygiene. 20, pp. 212-218. doi: https://doi.org/10.4269/ajtmh.1971.20.212.

Ulukanligil, M., Seyrek, A., Aslan, G., Ozbilge, H. and Atay, S. (2001). Environmental pollution with soil-transmitted helminths in Sanliurfa, Turkey. Memórias do Instituto Oswaldo Cruz. 96, pp. 903 - 909.

Uniting to Combat NTDs (2015). The Third Report: Country Leadership and Collaboration on NTDs.

Uniting to Combat NTDs (2014). Delivering on Promises and Driving Progress.

Uno, W. and Simpson-Hebert, M. (2004). Ecological sanitation: Revised and enlarged edition. Stockholm Environmental Institute. Stockholm. 
USEPA (1999). Environmental Regulations and Technology. Control of Pathogens and Vector Attraction in Sewage Sludge. United States Environmental Protection Agency, Centre for Environmental Research. Ohio.

USEPA (1999). Environmental Regulations and Technology: Control of Pathogens and Vector Attraction in Sewage Sludge.

Villamizar, E., Mendez, M., Bonilla, E., Varon, H. and de Ontra, S. (1996). Ascaris lumbricoides infestation as a cause of intestinal obstruction in children: Experience with 87 cases. Journal of Pediatric Surgery. 31, pp. 201-205. doi: 10.1016/S0022-3468(96)90348-6.

Vinnerås, B., Hedenkvist, M., Nordin, A. and Wilhelmson, A. (2009). Peepoo bag: self-sanitising single use biodegradable toilet. Water Sci Technol. 59, pp. 1743-1749. doi: 10.2166/wst.2009.184.

Walls, K. (2015). Health implications of increasing reuse of wastewater as an adaption to climate change. journal of Environmental Engineering and Ecological Science. 4, pp. 1-7. doi: 10.7243/2050-1323-4-2.

Wang, J.Q. (1999). Reduction of microorganisms in dry sanitation due to different adsorbents under low temperature conditions. 9th Stockholm Water Symposium. 9th Stockholm Water Symposium. Stockholm, Sweden. pp. 396-398.

Wani, I., Maqbool, M., Amin, A., Shah, F., Keema, A., Singh, J. et al. (2010). Appendiceal ascariasis in children. Annals of Saudi Medicine. 30, pp. 63-66. doi: 10.4103/0256-4947.59380.

Wharton, D. (1980). Nematode egg-shells. Parasitology. 81, pp. 447-463. doi: 10.1017/S003118200005616X.

WHO (2011). Helminth control in school-age children: a guide for managers of control programmes. 2nd ed. WHO. Geneva.

WHO (2011). WHO Model Lists of Essential Medicines. 2011,.

WHO (2006). Preventive chemotherapy in human helminthiasis. WHO. Geneva. pp. 74.

WHO (1987). Prevention and control of parasitic infections. WHO. Geneva. pp. 88.

Windberg, C. (2009). Assessment of the appropriateness of compost toilets in Sri Lanka: 17 key questions. Report 2 of 3 from Evaluation of the appropriateness of ecological sanitation in relation to the social, cultural and economic and financial context of Sri Lan. UNICEF. pp. 52.

Wolgast, M. (1993). Recycling system. WM-Ekologen ab, Stockholm, Sweden.

Xianmin, Z., Weidong, P., Crompton, D.W.T. and Jaingqin, X. (1999). Patterns of transmission, prevalence and intensity of soil transmitted helminthiasis in Nsukka Zone, Enugu State, Nigeria. Transactions of the Royal Society of Tropical Medicine and Hygiene. 93, pp. 561-564.

Yadav, A.K. (2003). Development and survival of Ascaris lumbricoides eggs under the high-rainfall and humid conditions prevailing in Meghalaya, India. Proceedings of Zoological Society of Calcutta. 56, Zoological Society of Calcutta. Calcutta, India. pp. 109-112.

Yanko, W.A. (1987). Occurrence of pathogens in distribution and marketing municipal sludges. National Technical Information Service. Springfield, Virginia.

Yi, W. (1984). Treatment of 155 cases with biliary ascariasis with decoction of Fructus mume. Zhejiang Journal of Traditional Chinese Medicine. 1, pp. 14.

Zargar, S.A. and Khuroo, M.S. (1990). Management of biliary ascariasis in children. Indian Journal of Gastroenterology. 9, pp. 321.

Ziegelbauer, K., Speich, B., Mäusezahl, D., Bos, R., Keiser, J. and Utzinger, J. (2012). Effect of Sanitation on SoilTransmitted Helminth Infection: Systematic Review and Meta-Analysis. PLOS Medicine. 9, pp. 1-17. doi: 10.1371/journal.pmed.1001162. 